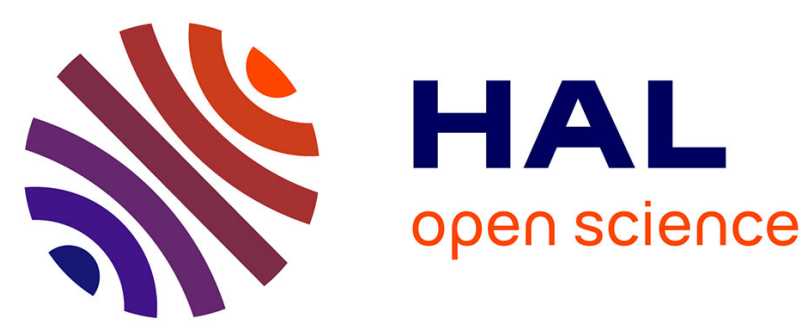

\title{
Turpanopitys taoshuyuanense gen. et sp. nov., a novel woody branch discovered in Early Triassic deposits of the Turpan Basin, Northwest China, and its palaeoecological and palaeoclimate implications
}

Xiao Shi, Jianxin Yu, Jean Broutin, Denise Pons, Camille Rossignol, Sylvie Bourquin, S. Crasquin, Qiang Li, Wenchao Shu

\section{To cite this version:}

Xiao Shi, Jianxin Yu, Jean Broutin, Denise Pons, Camille Rossignol, et al.. Turpanopitys taoshuyuanense gen. et sp. nov., a novel woody branch discovered in Early Triassic deposits of the Turpan Basin, Northwest China, and its palaeoecological and palaeoclimate implications. Palaeogeography, Palaeoclimatology, Palaeoecology, 2017, 468, pp.314-326. 10.1016/j.palaeo.2016.12.026 . hal-01422305

\section{HAL Id: hal-01422305 https://hal.science/hal-01422305}

Submitted on 2 Sep 2021

HAL is a multi-disciplinary open access archive for the deposit and dissemination of scientific research documents, whether they are published or not. The documents may come from teaching and research institutions in France or abroad, or from public or private research centers.
L'archive ouverte pluridisciplinaire HAL, est destinée au dépôt et à la diffusion de documents scientifiques de niveau recherche, publiés ou non, émanant des établissements d'enseignement et de recherche français ou étrangers, des laboratoires publics ou privés. 


\section{Accepted Manuscript}

Turpanopitys taoshuyuanense gen. et sp. nov., a novel woody branch discovered in Early Triassic deposits of the Turpan Basin, Northwest China, and its palaeoecological and palaeoclimate implications

Xiao Shi, Jianxin Yu, Jean Broutin, Denise Pons, Camille Rossignol, Sylvie Bourquin, Sylvie Crasquin, Qiang Li, Wenchao

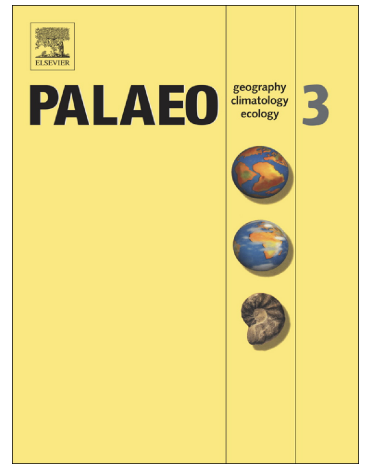
Shu

PII: $\quad$ S0031-0182(16)30902-6

DOI: $\quad$ doi: $10.1016 /$ j.palaeo.2016.12.026

Reference: $\quad$ PALAEO 8114

To appear in: $\quad$ Palaeogeography, Palaeoclimatology, Palaeoecology

Received date: $\quad 27$ July 2016

Revised date: $\quad 15$ December 2016

Accepted date: 19 December 2016

Please cite this article as: Xiao Shi, Jianxin Yu, Jean Broutin, Denise Pons, Camille Rossignol, Sylvie Bourquin, Sylvie Crasquin, Qiang Li, Wenchao Shu, Turpanopitys taoshuyuanense gen. et sp. nov., a novel woody branch discovered in Early Triassic deposits of the Turpan Basin, Northwest China, and its palaeoecological and palaeoclimate implications. The address for the corresponding author was captured as affiliation for all authors. Please check if appropriate. Palaeo(2016), doi: 10.1016/j.palaeo.2016.12.026

This is a PDF file of an unedited manuscript that has been accepted for publication. As a service to our customers we are providing this early version of the manuscript. The manuscript will undergo copyediting, typesetting, and review of the resulting proof before it is published in its final form. Please note that during the production process errors may be discovered which could affect the content, and all legal disclaimers that apply to the journal pertain. 


\title{
Turpanopitys taoshuyuanense gen. et sp. nov., a novel woody
}

\section{branch discovered in Early Triassic deposits of the Turpan Basin,}

\section{Northwest China, and its palaeoecological and palaeoclimate}

\section{implications}

Xiao Shi ${ }^{\mathrm{a}, \mathrm{b}, \mathrm{c}}$, Jianxin $\mathrm{Yu}^{\mathrm{a}, \mathrm{b}, *}$, Jean Broutin ${ }^{\mathrm{c}}$, Denise Pons $^{\mathrm{c}}$, Camille Rossignol ${ }^{\mathrm{d}, \mathrm{e}}$, Sylvie Bourquin $^{\mathrm{d}}$, Sylvie Crasquin ${ }^{\mathrm{c}}$, Qiang $\mathrm{Li}^{\mathrm{a}, \mathrm{b}}$, Wenchao $\mathrm{Shu}^{\mathrm{a}, \mathrm{b}}$

${ }^{\text {a }}$ State Key Laboratory of Biogeology and Environmental Geology, Wuhan 430074, China

${ }^{\mathrm{b}}$ School of Earth Sciences, China University of Geosciences, Wuhan 430074, China

${ }^{\mathrm{c}}$ Sorbonne Universités, CR2P-UPMC Paris 6-MNHN-CNRS, 75005 Paris, France

d Géosciences Rennes UMR CNRS 6118, Université Rennes 1, 35042 Rennes cedex, France

e Géohydrosystèmes Continentaux, EA 6293, Université François Rabelais, 37200 Tours, France

*Corresponding authors

E-mail:

Jianxin Yu: yujianxin@cug.edu.cn

\begin{abstract}
A novel well-preserved woody branch, Turpanopitys taoshuyuanense gen. et sp. nov. was collected in the early Triassic terrestrial deposits in the Turpan Basin, Northwest China. The permineralized wood is characterized by a heterogeneous pith, endarch primary xylem and Protophyllocladoxylon-type secondary xylem. The pith consists of parenchyma cells and supporting diaphragms formed by brick-like sclerenchyma cells. The quantitative growth-ring analyses of T. taoshuyuanense indicate that the species was evergreen, the leaf longevity
\end{abstract}


being comprised between 3 to 15 years. T. taoshuyuanense might indicate a warm humid climate with short dry periods in the Turpan basin in the Early Triassic. The Protophyllocladoxylon-type woods were widely distributed in different climate zone in both southern and northern hemispheres during the Palaeozoic and Early Triassic. The growth rings of the woods with Protophyllocladoxylon-type secondary xylem are good indicator for the palaeoclimate. The new specimen indicates that a warm humid climate with irregularly distributed short dry periods in the Early Triassic Turpan basin.

Keywords: Turpanopitys taoshuyuanense gen. et sp. nov.; Palaeoecology; Palaeobiogeographic distribution; Early Triassic; Turpan Basin

\section{Introduction}

Five mass extinctions were recognized in the Phanerozoic in animal families (Jablonski, 1985), while only two major extinctions could be clearly recognized in plant families (Cascales-Miñana and Cleal, 2013). The end-Permian mass extinction is the only one affecting conjointly terrestrial ecosystems (including plants) and marine ecosystems (Twitchett et al., 2001; Cascales-Miñana and Cleal, 2013). Based on the palaeobotanical data for the end-Permian from Northern China Block, several environmental stresses that affected end Permian terrestrial ecosystems were identified, for instance, wind activity, fungal proliferation, water stress, elevated atmospheric $\mathrm{CO}_{2}$ concentration and wildfire (Wang and Zhang, 1998). After this severest extinction, the physical environments remained very disturbed during the next 5-6 Myr (Retallack et al., 2011; Chen and Benton, 2012; Sun et al., 2012; Retallack, 2013; Benton and Newell, 2014). As a result, plant diversity did not return to the pre-extinction levels until the Late Triassic (Chen and Benton, 2012). 
The reconstruction of palaeoenvironmental conditions prevailing during the end Permian mass extinction and subsequent Triassic recovery is essential to better constrain the potential causes and mechanisms that lead to this major biotic turnover. Anatomical features observed from fossils, including plants, provide key palaeoecologic and palaeoclimatic information (e.g., Royer et al., 2005; Knoll et al., 2007). In this paper, we describe a new woody branch discovered in the transitional Permian-Triassic deposits of the Guodikeng Formation in the Turpan Basin, Northwest China. The results of a quantitative growth-ring analysis are good enough to give accurate palaeoecological interpretations. A bibliographical survey allowed us to analyse the palaeogeographic distribution of Protophyllocladoxylon-type woods during late Palaeozoic.

\section{Geological setting, materials, and methods}

The Turpan Basin, located in the Xinjiang Uygur autonomous Province, northwest China (Fig. 1), covers about $53,500 \mathrm{~km}^{2}$, and constitutes the third lowest exposed terrestrial point on the earth's surface. The present boundaries of the basin are the Bogda and Haerlike Mountains to the north and the Juluotage Mountains to the south. During the Late Permian to the Early Triassic, the basin was located on the Junggar block that constituted a part of the Pangea supercontinent (e.g., Domeier and Torsvik, 2014; Fig. 2). The Turpan Basin was further located on the northwest coast of a Palaeotethys branch (Fig. 2) that progressively disappeared as a result of a northwestward subduction (e.g., Xiao et al., 2009). The Turpan Basin consequently migrated northward from 40 to $50^{\circ} \mathrm{N}$ palaeo-latitude during KungurianWuchiapingian time (McElhinny et al., 1981; Sengor and Nat'lin, 1996; Ziegler et al., 1997; Scotese, 2001; Yang et al., 2010). Late Permian to Early Triassic deposits mainly correspond to alluvial and lacustrine settings (e.g., Greene et al., 2005) emplaced in many small grabens 
and half grabens (Allen et al., 1995; Sengor and Nat'lin, 1996; Yang et al., 2007, 2010).

The Taoshuyuan section is located on northern side of the Turpan Basin, in the foothill of the Bogda Mountains (Fig. 1). The section crops out on the southern flank of a WNW-ESE trending axial plan syncline (Fig. 1C). The lithostratigraphy, biostratigraphy and cyclostratigraphy of this area are well established (Zhang, 1981; Liao et al., 1987; Cheng et al., 1996; Wartes et al., 2002; Zhu et al., 2005; Yang et al., 2007, 2010).

The specimen was collected from the Guodikeng Formation in the southern limb of Taoshuyuan syncline (GPS: $43^{\circ} \quad 57^{\prime} \quad 59.6^{\prime \prime} \quad \mathrm{N}, 88^{\circ} \quad 52^{\prime} \quad 02.2^{\prime \prime}$ E; Fig. 1C). The fossil plants, spores and pollen assemblages, palaeomagnetism and $\delta^{13} \mathrm{C}_{\mathrm{org}}$ data suggest the PermianTriassic boundary within 61-66 m below the basalmost deposits of the Jiucaiyuan Formation in the northern limb of the Taoshuyuan syncline (Sun, 1989; Li et al., 2004; Cao et al., 2008; Liu, 2010). The sample has been found in fine-grained sandstone deposits, $25 \mathrm{~m}$ below the basalmost beds of Jiucaiyuan Formation, with current and wave ripples, attributed to coastal lake environment (Fig. 3). In the silty clay level above the bed where we collected the wood specimen, Cheng et al. (1996) found fossils of vertebrate Lystrosaurus (Fig. 3). Lystrosaurus is classically considered as an Early Triassic marker (succeeding to the Permian Dicynodon, e.g., Lucas, 1998; Lucas, 2009). In consequence, the upper part of the Guodikeng Formation is traditionally considered as Early Triassic in age (Fig. 3). However, a stratigraphic overlap of Dicynodon and Lystrosaurus has been documented in the closely located Junggar Basin (e.g., Metcalfe et al., 2009) as well as in other part of the world (e.g., Smith and Ward, 2001 for the Karoo Basin, South Africa). As a result, although the exact location of the PermianTriassic boundary in this section is still unknown, the bed where we found the specimen can be considered as Early Triassic in age.

To investigate the wood fossils, thin-sections were made using conventional cutting and polishing methods for optical microscopic observations. Slides were photographed with 
Panasonic a DMC-FZ28 digital camera. The anatomy of the wood was studied using a microscope Leica DM4000B. Photomicrographs were taken with Nikon D300 digital camera. Images in plates are basically processed and stitched together by Adobe Photoshop CS v. 6 . All the specimens and slides are housed in the State Key Laboratory of Biogeology and Environmental Geology, China University of Geosciences (Wuhan), under catalogue number: XTT-C-4.

To infer intraseasonal conditions and leaf longevity patterns of the tree, Falcon-Lang (2000a) developed the CSDM curve (Cumulative Sum of the Deviation from Mean diameter). We selected five adjacent growth rings and measured the radial diameter of five adjacent rows of cells for each growth ring to construct the CSDM curve. The radial diameters of the cells were then averaged using the method of Falcon-Lang (1999).

\section{Systematic palaeontology}

CLASS Coniferopsida Sternberg, 1820

ORDER Coniferophyte Sternberg, 1820

FAMILY Incertae sedis

GENUS Turpanopitys gen. nov. Shi, Yu, Broutin and Pons

Genus diagnosis: Pith heterogeneous with parenchyma cells and supporting diaphragms. Primary xylem endarch. Tracheids in primary xylem with annular, helical and reticulate thickenings. Secondary xylem homoxylic. Tracheids with araucarian radial pitting. Xylem rays homogeneous. Cross-fields with simple pits. Vertical parenchyma cells and secretory cells absent.

Etymology: The generic name is derived from the Turpan Basin, where the type specimen was collected. 
Holotype: Turpanopitys taoshuyuanense gen. et sp. nov. Shi, Yu, Broutin and Pons

Repository: State Key Laboratory of Biogeology and Environmental Geology, China University of Geosciences (Wuhan), Wuhan, China.

Type locality: Taoshuyuan, Turpan, Xinjiang Uygur Autonomous Region, PR China. (Fig. 1)

Stratigraphic horizon and age: Upper part of Guodikeng Formation, Early Triassic.

Etymology: The specific name is derived from the Taoshuyuan syncline, where the type specimen was collected.

Type species: Turpanopitys taoshuyuanense gen. et sp. nov. Shi, Yu, Broutin and Pons

Specific diagnosis: Pith heterogeneous with parenchyma cells and supporting diaphragms. Diaphragms consist of brick-like sclerenchyma cells. Sclerenchyma cells vertically regularly aligned. Primary xylem endarch. Tracheids in primary xylem with annular, helical and reticulate thickenings. Secondary xylem homoxylic, with indistinct growth rings. Tracheids with uni- to triseriate araucarian pits. Xylem rays uniseriate (rarely biseriate), homogeneous, 1-40 cells high. Cross-fields with 1 (up to 3), rectangular, oval or round, simple, sometimes slightly areolate pits. Vertical parenchyma cells and secretory cells absent.

\section{Description}

The calcified fossil wood piece is about $12.5 \mathrm{~cm}$ long with a maximum diameter of $9.0 \mathrm{~cm}$ (Fig. 4A). Interestingly, a young lateral branchlet emerges horizontally from the main branch (Fig. 4B, C). No cortical tissues are preserved. The pith was preserved only in the branchlet. In the branch, it was impossible to get any slides of the pith. Several leaf traces, helically arranged, occur in the secondary xylem of the branchlet and cross the growth-ring boundary (Fig. 4C, E). This indicates that the species is evergreen (Falcon-Lang and Cantrill, 2001). 
Pith - The pith is circular in outline. Along the direction of the branchlet extension, the pith diameter increases from 0.6 to $1.65 \mathrm{~cm}(\mathrm{~L}=5.5 \mathrm{~cm})(\mathrm{Fig}$. 5A). Two slides along the transversal direction and two slides along the radial direction were made. The pith of the branchlet is heterogeneous. It consists of parenchyma cells and diaphragms made of sclerenchyma-like cells. The parenchyma cells are isodiametric, circular or polygonal in transverse section, diameter 25 to $152.5 \mu \mathrm{m}$ (Fig. 3D). The wall is mean $2.4 \mu \mathrm{m}$ thick. Some cell walls are dark brown. Intercellular spaces are visible.

Seven complete diaphragms can be observed in the present specimen (Fig. 5A). In the radial section, the diaphragms are lense-like (Fig. 5A, B). Two perpendicular radial sections of the pith indicate that these diaphragms are true platforms (Fig. 5C, D). The intact diaphragms are horizontal or slightly curved, but three incomplete diaphragms at the top of the branchlet appear bent (Fig. 5A). Their thickness decreases gradually from the middle part of the pith to the periphery and reduces to one or two cells at the contact with the primary xylem or the initial secondary xylem (Fig. 5E, F). The middle part of the diaphragm is 0.32 to $1.24 \mathrm{~mm}$ thick and only one or two cells thick at the peripheral ends.

The sclerenchyma cells of the diaphragms are brick-like. In radial section, the sclerenchyma cells are very close and vertically regularly arranged in lines. The intercellular spaces are absent. The sclerenchyma cells are ca. $7.5 \times 29$ to $40 \times 76 \mu \mathrm{m}$ in size with 2.5 to 15 $\mu \mathrm{m}$ thick walls (Fig. 6A). The pith cells display lining-like structures inside the cell lumens and the cell walls are separated in some area. These artifact structures are caused by white rot.

Primary xylem - The primary xylem shows endarch maturation (Fig. 6B). The primary xylem tracheids are ca. 17.5 to $25 \mu \mathrm{m}$ wide and show annular, helical and reticulate thickenings (Fig. 6C). 
Secondary xylem - The secondary xylem is pycnoxylic, with tracheids and parenchymatous rays. Eight growth rings were preserved in the transverse section of the main branch (Fig. 6D). Early wood tracheids are circular or polygonal, while late wood ones are elliptical or rectangular. The percentage of late wood is $8.79-19.57 \%$. The tracheids are 16 to $66 \mu \mathrm{m}$ in diameter. The lumens of some tracheids are fully filled by tyloses.

In the radial section, pits on the tracheid walls are of araucarian type. In the branchlet, they are uniseriate $(24 \%)$ or biseriate $(74 \%)$, occasionally triseriate $(2 \%)$ (Fig. $6 \mathrm{E}, \mathrm{F})$, while in the main branch, they are uniseriate $(60 \%)$ or biseriate $(40 \%)$ (Fig. 7A). When uniseriate, the pits are contiguous, circular or flattened, 5-15 $\mu \mathrm{m}$ from the tracheid internal walls, and the flattening index is $0.58-0.95$; when biseriate or triseriate, the pits are alternate, crowded hexagonal, close to the internal wall of the tracheids, and the flattening index is $0.63-0.96$. Near to the pith, some opposite pits can be observed $(<1 \%)$. The pits are 7.5 to $20 \mu \mathrm{m}$ in diameter, with circular or elliptical apertures.

Cross-field pits are rectangular, oval or round. They are simple, sometimes slightly areolate. In the branchlet, there is 1 or 2 , rarely 3 , pits in each cross-field unit (Fig. 7B, C). In the main branch there is only one pit in each cross-field unit (Fig. 7D). The pits are $9 \times 12 \mu \mathrm{m}$ to $28 \times 35 \mu \mathrm{m}$ (width $\times$ height).

The information for the tangential view is based only on the main branch. The lumens of tracheids are secondarily septate by numerous tyloses originating from ray cells (Fig. 7F). The homogeneous rays consist of elliptical or sub-rectangular parenchyma cells. The horizontal and tangential ray walls are smooth. They are uniseriate, or very rarely biseriate $(<$ 1\%). Rays are constituted by 1-15 (> 90\%), up to 40, cells (30-1110 $\mu \mathrm{m})$ high (Fig. 7E). There are 35 rays per square millimetre. Ray cells are 12.5 to $27.5 \mu \mathrm{m}$ wide, and 17.5 to 32.5 $\mu \mathrm{m}$ high. Vertical parenchyma cells and secretory canals are absent. 


\section{Comparisons}

The anatomical features of Turpanopitys gen. nov. closely resemble some extinct and extant conifers that also display a heterogeneous pith, endarch primary xylem and thick pycnoxylic secondary xylem. As the anatomy of the pith and primary xylem constitute critical criteria for the classification of gymnosperms woods (Lepekhina, 1972; Pant and Singh, 1987; Feng et al., 2011), we thus consider Turpanopitys gen. nov. as a coniferophyte of uncertain systematic affinity.

Turpanopitys gen. nov. possesses unique solid lenticular diaphragms in the pith. All the sclerenchyma cells of the diaphragms are morphologically different and smaller than the parenchyma cells and closely arranged without intercellular space. The sclerenchyma cell walls are thicker than that of parenchyma cell. Based on these characters, these diaphragms play clearly a role of support to the pith.

The secondary xylem of Turpanopitys gen. nov. is identical to Protophyllocladoxylon Kräusel: (1) presence of growth rings, (2) araucarian radial pitting of tracheids, (3) simple large oval or round cross-field pits, (4) absence of axial parenchyma and resin canals, (5) unpitted ray walls. About six morphogenera of fossil woods with a Protophyllocladoxylontype secondary xylem and different structures of pith and primary xylem have been documented as far as we know from the Paleozoic and early-middle Triassic (Table 1). Among them, the pith of Junggaropitys Shi, Yu, Broutin and Pons, 2015 is homogeneous that is different from Turpanopitys gen. nov.

In some Late Palaeozoic coniferophytes related to the walchian Voltziales clade, sclerotic nests occur in the piths (e.g., Barthelia, Emporia, and Hanskerpia from the Upper Pennsylvanian of Hamilton Quarry, Kansas, U.S.A.; Macdonaldodendron from the Lower Permian and Upper Pennsylvanian, New Mexico, U.S.A.) (Rothwell and Mapes, 2001; Rothwell et al., 2005; Hernandez-Castillo et al., 2009a, 2009b, 2009c; Falcon-Lang et al., 
2014, 2016). In most of these genera, the isolated sclerotic nests are irregularly distributed in the piths. But in Emporia, the sclerotic diaphragms occur as those in Turpanopitys. However, the secondary xylem of walchian conifer is characterised by predominantly uniseriate tracheid pitting and typically shows only one cupressoid pit per cross-field (Rothwell and Mapes, 2001; Rothwell et al., 2005; Hernandez-Castillo et al., 2009a, 2009b, 2009c; Falcon-Lang et al., 2014, 2016). That is different from the Protophyllocladoxylon-type secondary xylem in the new genus.

Septomedullopitys Lepekhina 1972 was first found documented in Russia. S. szei Wan, Yang and Wang 2014 was first described in the Late Permian deposition of Turpan Basin. In the pith of $S$. szei, parenchymatous bands composed of closely arranged brick-like cells are observed. However, these bands are irregularly distributed in the pith, of $S$. szei which is different from the lenses-like diaphragms in the present specimen. Besides, the pith of $S$. szei is septate and heterocellular, long secretory ducts with dark contents being distributed throughout the pith. It differs from the pith of Turpanopitys gen. nov., which is solid and lacks secretory ducts.

Phyllocladopitys Kräusel, 1928 was first collected from southwest Africa. It possesses a Protophyllocladoxylon-type secondary xylem and homogeneous pith. However, the primary xylem of Phyllocladopitys is mesarch or exarch, compared to the endarch primary xylem of Junggaropitys.

Medullopitys Kräusel, 1928 and Megaporoxylon (Kräusel, 1956) were found in the Early Permian sequences in southwest Africa. They both possess large heterogeneous piths but without diaphragms, contrary to Turpanopitys gen. nov.

Cordaixylon andresii Césari, Álvarez-Vázquez, Méndez-Bedia, Álvarez-Laó, Turrero and Arbizu, 2015 was documented from Late Pennsylvanian (Stephanian) outcrops at Arnao beach, Spain. It has a Protophyllocladoxylon-type secondary xylem, but its pith is 
homogeneous with isodiametric parenchyma cells and differs from the pith in Turpanopitys gen. nov.

Austroscleromedulloxylon (Mussa, 1980) was erected as a genus based on samples from the Early Permian of Brazil (Mussa, 1980, 1986; Crisafulli, 1998). In its pith, the supporting sclerenchymatous diaphragms are present and display a very similar morphology to those of Turpanopitys gen. nov. However, the secondary xylem of Austroscleromedulloxylon is of Australoxylon-type instead of Protophyllocladoxylon.

Nandorioxylon saksenae, described by Biradar and Bonde (1981) based on specimens collected from the Late Permian of India, and Xuanweioxylon He, Wang, Hilton and Shao, 2013 was discovered in strata from the Late Permian of South China, display some similarities with those of Turpanopitys gen. nov. In the piths of Nandorioxylon saksenae and Xuanweioxylon, sclerenchymatous sheaths form peripheral annuli in radial direction that is different from the complete diaphragms in Turpanopitys gen. nov. Additionally, the secondary xylem of Nandorioxylon is also of Araucarioxylon-type that is different from Turpanopitys gen. nov. Xuanweioxylon also contrast with Turpanopitys gen. nov., because the tracheids of the latter display scalariform bordered pits.

\section{Discussion}

\subsection{Palaeoecological implications}

Growth-ring patterns provide essential information to determine the tree habit (e.g., FalconLang, 2000a, 2000b, 2003; Brea et al., 2008, 2011; Shi et al. 2015). The radial diameter of five adjacent rows of cells were measured to construct the CSDM curve (Fig. 8). We

calculated four parameters based on the CSDM curves: (1) skew of CSDM curves, (2) percentage of late wood, (3) percentage of cell diminution in a ring increment and (4) Ring 
Markedness Index (RMI). (Fig. 9). Deciduous conifers have dominantly left-skewed CSDM or symmetrical curves, whereas evergreen conifers have dominantly right-skewed CSDM curves. The CSDM curves of Turpanopitys taoshuyuanense are from $+4.92 \%$ to $+82.41 \%$ (mean percentage of skew $+38.18 \%$ ), right-skewed, suggesting that this species was evergreen. This result is consistent with the leaf trace characteristics of Turpanopitys taoshuyuanense (see section 4).

The percentage of late wood in conifer woods could be related to foliar retention (Falcon-Lang, 2000a, 2000b). The late wood development may be strongly influenced by both leaf longevity and the intensity of climate seasonality. The percentage of late wood in Turpanopitys taoshuyuanense is $8.79-19.57 \%$, with a mean of $13.66 \%$. The percentage of cell diminution ranges from $60.61 \%$ to $72.00 \%$, with an average of $73.02 \%$. The RMI varies between $5.86 \%$ and $14.12 \%$, with a mean of $9.48 \%$ (Table 2). Falcon-Lang (2000a) found a strong inverse linear relationship between the leaf retention and the different quantitative parameters of growth rings (percentage of skew, late wood, cell diminution and RMI values) in the group of extant conifers. The results show that the foliar retention of Turpanopitys taoshuyuanense is similar to those of extant conifers with 3-15 years of foliar retention (Table 3).

\subsection{Palaeoclimatic conditions}

The growth ring analysis is a powerful tool to deduce palaeoclimatic conditions that prevailed during the tree growth (e.g., Schweingruber, 1992, 1996; Falcon-Lang, 2000a, 2000b, 2003; Brea et al., 2008, 2011). The the mean radial diameter of five adjacent rows of cells for each growth ring is fluctuant (Fig. 8). Variability in mean cell diameters may result from fluctuations in water supply or other environmental disturbances.

But the factors controlling the formation of growth rings are very complex. Firstly, the 
growth ring studies must include a taxonomic analysis (Brison et al. 2001). To recognise whether the growth-ring type can indicate the climate conditions, we investigate the palaeobiogeographic distribution of Protophyllocladoxylon-type woods in the Palaeozoic and Early Triassic.

Zhang et al. (2010) investigated the distribution of Protophyllocladoxylon woods without pith from the Mississipian (Early Carboniferous) to the Palaeogene. Six species of Protophyllocladoxylon-type woods were found from the late Palaeozoic (Table 4). The four species described in the southern hemisphere were found in the cool temperate zone. However, Protophyllocladoxylon-type woods of the northern hemisphere were found in different climatic zones. Late Permian P. henanense (Yao et al., 1994) occurred in the tropical areas, while $P$. jingyuanense (Zhang et al., 2010), from the early Carboniferous North China block, lived in an arid climatic zone.

Ten species belonging to five morphogenera of coniferous fossil woods with a Protophyllocladoxylon-type secondary xylem from the late Palaeozoic have been documented (Table 5). All the species found in the southern hemisphere were distributed in the cool temperature zone. (Fig. 10).

Cordaixylon andresii Césari, Álvarez-Vázquez, Méndez-Bedia, Álvarez-Laó, Turrero and Arbizu, 2015 was documented from late Pennsylvanian Spain. During the Pennsylvanian, Spain was located in the equatorial area. Protophyllocladoxylon henanense Yao, Liu and Zhang was found in the Early Permian deposits of North China block, located in the tropical area. This species does not show growth rings as well.

Maheshwari (1972) has investigated the fossil woods from the Permian Antarctica where the climate was cool-temperate (Boucot et al., 2009). He evidenced that Protophyllocladoxylon dolianitii Mussa 1958, Magaporoxylon antarctium Maheshwari 1972 and Magaporoxylon canalosum Maheshwari 1972 all possessed the Protophyllocladoxylon- 
type secondary xylem. The growth-ring types of $M$. canalosum and $M$. antarctium are hard to distinguish in Maheshwari's article. The growth rings of $P$. dolianitii show thick latewood.

Septomedullopitys szei Wan, Yang and Wang, 2014 has been found in the Tarlong area of Turpan Basin in the Late Permian deposits. The climate was considered to be humid climate with short-term, nonperiodic droughts. The growth rings of $S$. szei show a very thin band of latewood.

In consequence, the Protophyllocladoxylon-type woods were widely distributed in the southern and northern hemispheres during the Palaeozoic and Early Triassic. The growth rings of the woods with Protophyllocladoxylon-type secondary xylem can be used as indicator of palaeoclimate.

The species was evergreen. Thus, the leaf abscission is not the reason for the growthring formation. Growth rings displaying subtle ring boundaries are related to weakly developed climate seasonality (Falcon-Lang, 1999). During the Late Permian to Early Triassic, palaeoclimatic reconstruction shows a temperate climate in this area (e.g., Kiehl and Shields, 2005; Péron et al., 2005; Boucot et al., 2009), in accordance with the mean annual temperature of $7-15( \pm 4.4){ }^{\circ} \mathrm{C}$ estimated from palaeosols proxies from the Turpan Basin (Thomas et al., 2011). Consequently, the growth rings of Turpanopitys taoshuyuanense do not appear to be related to these relatively moderate annual temperature ranges. On the contrary, Late Permian to Early Triassic palaeosoils from the Turpan Basin display features indicative of variable soil moisture regimes (Thomas et al., 2011). Thus, we speculate that dry episodes trigged the formation of growth rings. Moreover, the width of growth rings ranges from 3.8 $\mathrm{mm}$ to $8.4 \mathrm{~mm}$. Variability in mean cell diameters may result from fluctuations in water supply or other environmental disturbances (Fig. 8). It indicates that the growing environment was not uniform. In conclusion, Turpanopitys taoshuyuanense developed under a mainly warm humid climate condition with short dry periods or of hydric stresses due to the 
irregularity of water supplies.

\section{Conclusions}

The genus Turpanopitys gen. nov. is discovered for the first time in the Early Triassic deposits of the Turpan Basin. This genus displays diaphragms in the pith, a unique characteristic that distinguish it from any other species with Protophyllocladoxylon-type wood reported up to now. The presence of diaphragms within the pith plays a supportive role. The quantitative growth-ring analysis allows hypothesizing that $T$. taoshuyuanense was an evergreen gymnosperm, the foliar retention being probably of 3-15 years. Morphometric characteristics displayed by $T$. taoshuyuanense indicates it developed under irregularly stressed warmtemperate conditions.

The discovery of the new genus Turpanopitys gen. nov. in the Guodikeng Formation of the Turpan basin contributes to a better understanding of the plant diversity during Permian-Triassic transition. Wang (1996) described the process of vegetation recovery from the end Permian mass extinction in North China. He pointed out that the vegetation recovery was completed in the latest Middle Triassic. For the Turpan Basin, abundant conifer fossil woods were found in the early Early Triassic sequences. Looy et al. (1999) noted that in most locations the floral recovery was associated with the re-establishment of coniferous forests. These new discoveries are in good agreement with the Looy et al. statement. The occurrence of Turpanopitys taoshuyuanense gen. et sp. nov. might indicate a warm humid climate with irregularly distributed short dry periods and Palaeo-Tethys megamonsoons did not influence the Turpan basin long the east coast of mid-latitude Pangaea in the Early Triassic. We hope to find more evidences (e.g. palynological data, sedimentological data and organic geochemistry data) to know more about the biodiversity and the climatic conditions of that period. 


\section{Acknowledgments}

The authors are thankful to Prof. Wu Zhang and Prof. Shaolin Zheng of Shenyang Institute of Geology and Mineral Resources and Anais Boura of Pierre et Marie Curie University for their help in identifying the fossil woods and providing relevant materials. We thank Dr. Daoliang Chu and Mr. Wei Zhang of China University of Geosciences for collecting the sample. We also thank two anonymous reviewers for extremely helpful feedback and constructive comment on the article. The study was supported by National Natural Science Foundation of China (Grant No. 41572005, 41272024).

\section{References}

Allen, M.B., Sengor, A.M.C., Natal'in, B.A., 1995. Junggar, Turfan and Alakol basins as Late Permian to ?Early Triassic extensional structures in a sinistral shear zone in the Altaid orogenic collage, Central Asia. Journal of the Geological Society 152 (2), 327-338.

Benton, M.J., Newell, A.J., 2014. Impacts of global warming on Permo-Triassic terrestrial ecosystems. Gondwana Research 25 (4), 1308-1337.

Biradar, N.V., Bonde, S.D., 1981. Nandorioxylon saksenae gen. et sp. nov. - a new gymnospermous wood from the Kamthi Stage of Chandrapur District, Maharashtra State, India. Geophytology 11, 90-95.

Boucot, A.J., Chen, X., Scotese, C.R., Fan, J.X., 2009. Phanerozoic global climatic reconstruction. Science Press, Beijing, 173 pp. (In Chinese)

Brea, M., Césari, S.N., 1995. An anatomically preserved stem from the Carboniferous of Gondwana: Phyllocladopitys petriellae Brea and Césari, sp. nov. Review of Palaeobotany and Palynology 86 (3), 315-323.

Brea, M., Artabe, A, Spalletti, L.A., 2008. Ecological reconstruction of a mixed Middle 
Triassic forest from Argentina. Alcheringa 32 (4), 365-393.

Brea, M., Matheos, S.D., Raigemborn, M.S., Iglesias, A., Zucol, A.F., Prámparo, M.B., 2011. Paleoecology and paleoenvironments of Podocarp trees in the Ameghino Petrified forest (Golfo San Jorge Basin, Patagonia, Argentina): constraints for early Paleogene paleoclimate. Geologica acta 9 (1), 13-28.

Brison, A.L., Philippe, M., Thevenard, F., 2001. Are Mesozoic wood growth rings climateinduced? Palaeobiology 27, 531- 538.

Cao, C., Wang, W., Liu, L., Shen, S., Summons, R.E., 2008. Two episodes of ${ }^{13}$ C depletion in organic carbon in the latest Permian: Evidence from the terrestrial sequences in northern Xinjiang, China. Journal of Asian Earth Sciences, 270(34): 251-257.

Cascales-Miñana, B., Cleal, C.J., 2013. The plant fossil record reflects just two great extinction events. Terra Nova 26 (3), 195-200.

Césari, S.N., Álvarez-Vázquez, C., Méndez-Bedia, I., Álvarez-Laó, D., Turrero, P., Arbizu, M., 2015. First report of permineralised plants in the Stephanian of Arnao (Asturias, northwestern Spain). Palaeogeography, Palaeoclimatology, Palaeoecology, 440, 475-486.

Chen, Z.Q., Benton, M.J., 2012. The timing and pattern of biotic recovery following the endPermian mass extinction. Nature Geoscience 5 (6), 375-383.

Cheng, Z.W., Wu, S.Z., Fang, X.S., 1996. The Permian-Triassic sequences in the southern margin of the Junggar Basin and the Turpan Basin, Xinjiang, China. In: Hongfei, Hou, Jinsong, Zhou (Eds.), Field Trip Guide, Volume 1, Stratigraphy, Paleontology, Sedimentology, Petroleum and Coal Geology. 30th International Geological Congress. Geological Publishing House, Beijing, China.

Crisafulli, A., 1998. Leños gimnospérmicos de la Formación Melo (Pérmico Inferior), Uruguay. Parte II. Stiloxylon, Polysolenoxylon y Bageopitys. Ameghiniana, 35 (2), 133140. 
Domeier, M., Torsvik, T.H., 2014. Plate tectonics in the late Paleozoic. Geoscience Frontiers 5, 303-350. doi:10.1016/j.gsf.2014.01.002

Falcon-Lang, H.J., 1999. The Early Carboniferous (Courceyan- Arundian) monsoonal climate of the British Isles. Geol. Mag. 136, 177-187.

Falcon-Lang, H.J., 2000a. A method to distinguish between woods produced by evergreen and deciduous coniferopsids on the basis of growth ring anatomy: a new palaeoecological tool. Palaeontology 43 (4), 785-793.

Falcon-Lang, H.J., 2000b. The relationship between leaf longevity and growth ring markedness in modern conifer woods and its implications for palaeoclimatic studies. Palaeogeography, Palaeoclimatology, Palaeoecology 160 (3), 317-328.

Falcon-Lang, H.J., Cantrill, D.J. 2001. Leaf phenology of some mid-Cretaceous polar forests, Alexander Island, Antarctica. Geological Magazine 138 (1), 39-52.

Falcon-Lang, H.J., 2003. Growth interruptions in silicified conifer woods from the Upper Cretaceous Two Medicine Formation, Montana, USA: implications for palaeoclimate and dinosaur. Palaeogeography, Palaeoclimatology, Palaeoecology 199 (3), 299-314.

Falcon-Lang, H.J., Kurzawe, F. and Lucas, S.G., 2014. Coniferopsid tree trunks preserved in sabkha facies in the Permian (Sakmarian) Community Pit Formation in south-central New Mexico, USA: Systematics and palaeoecology. Review of Palaeobotany and Palynology 200, 138-160.

Falcon-Lang, H.J., Kurzawe, F., Lucas, S.G., 2016. A Late Pennsylvanian coniferopsid forest in growth position, near Socorro, New Mexico, USA: Tree systematics and palaeoclimatic significance. Review of Palaeobotany and Palynology 225, 67-83.

Feng, Z.,Wang, J., Rößler, R., 2011. A unique gymnosperm from the latest Permian of China, and its ecophysiological implications. Review of Palaeobotany and Palynology 165 (1), 27-40. 
Greene, T.J., Carroll, A.R., Wartes, M., Graham, S.A., Wooden, J.L., 2005. Integrated Provenance Analysis of a Complex Orogenic Terrane: Mesozoic Uplift of the Bogda Shan and Inception of the Turpan-Hami Basin, NW China. J. Sediment. Res. 75, 251267. doi:10.2110/jsr.2005.019

Hernandez-Castillo, G.R., Stockey, R.A., Rothwell, G.W., Mapes, G., 2009a. A new voltzialean conifer, Emporia royalii sp. nov. (Emporiaceae) from the Hamilton Quarry, Kansas. Int. J. Plant Sci. 170, 1201-1227.

Hernandez-Castillo, G.R., Stockey, R.A., Rothwell, G.W., Mapes, G., 2009b. Whole plant reconstruction of Emporia lockardii (Emporiaceae) Voltziales and initial thoughts on Paleozoic conifer ecology. Int. J. Plant Sci. 170, 1056-1074.

Hernandez-Castillo, G.R., Stockey, R.A., Rothwell, G.W., Mapes, G., 2009c. Reconstruction of the Pennsylvanian-aged walchia conifer, Emporia cryptica sp. nov. (Emporiaceae, Voltziales). Rev. Palaeobot. Palynol. 157, 218-237.

Jablonski, D., 1985. Extinctions in the fossil record. Philosophical Transactions: Biological Sciences 344 (1307), 11-16.

Kiehl, J.T., Shields, C.A., 2005. Climate simulation of the latest Permian: Implications for mass extinction. Geology 33, 757-760. doi:10.1130/G21654.1

Knoll, A.H., Bambach, R.K., Payne, J.L., Pruss, S., Fischer, W.W., 2007. Paleophysiology and end-Permian mass extinction. Earth and Planetary Science Letters 256, 295-313. doi:10.1016/j.eps1.2007.02.018

Kräusel, R., 1928. Paläobotanische Notizen, X. Über ein Keuperholz mit cordaitem Mark. Senckenbergiana Lethaia 10, 247-250.

Kräusel, R., 1956. Hölzer aus dem Südlichen Gebiet der Karru-Schichten Südwest-Afrikas. Senckenbergiana Lethaia 37, 447-453.

Kräusel, R., Maithy, P.K., Maheshwari, H.K., 1961. Gymnospermous woods with primary 
structures from Gondwana rocks-a review. The Palaeobotanist 10, 97-107.

Lepekhina, V.G., 1969. Paleoxylological characterization of the Upper Palaeozoic coalbearing deposits of the Kuznetsk Basin. Translation Geological Institute Academy of Sciences USSR 130, 126-140 (In Russian).

Lepekhina, V.G., 1972. Woods of Palaeozoic pycnoxylic gymnosperms with special reference to North Eurasia representatives. Palaeontographica Abteilung B 138 (1-4), 44-106.

Li, Y., Li, J., Cheng, Z., Sun, D., Liu, J., Zheng, J., 2004. Study on paleomagnetism of Permian-Trassic in Pantaoyuan of Turpan, Xinjiang. Xinjiang Geology, 22(2): 136-142 (In Chinese with English abstract).

Liao, Z., Lu, L., Jiang, N., Xia, F., Song, F., Zhou, Y., Li, S., Zhang, Z., 1987. Carboniferous and Permian in the western part of the east Tianshan Mountains. Eleventh Congress of Carboniferous Stratigraphy and Geology, Guidebook Excursion 4. Beijing, China, 50 pp.

Liu, Z., 2000. The Peimian-Triassic Boundary on the Northern Margin of the Turpan-Hami Basin of Xinjiang, NW China. Journal of Stratigraphy 24(4): 310-314 (In Chinese with English abstract).

Looy, C.V., Brugman, W.A., Dilcher, D.L., Visscher, H., 1999. The delayed resurgence of equatorial forests after the Permian-Triassic ecologic crisis. Proceedings of the national Academy of Sciences 96(24), 13857-13862.

Lucas, S.G., 1998. Global Triassic tetrapod biostratigraphy and biochronology. Palaeogeography, Palaeoclimatology, Palaeoecology 143, 347-384. doi:10.1016/S00310182(98)00117-5

Lucas, S.G., 2009. Timing and magnitude of tetrapod extinctions across the Permo-Triassic boundary. Journal of Asian Earth Sciences 36, 491-502. doi:10.1016/j.jseaes.2008.11.016

Maheshwari, H.K., 1972. Permian wood from Antarctica and revision of some Lower 
Gondwana wood taxa. Palaeontographica Abteilung B 138, 1-43.

Metcalfe, I., Foster, C.B., Afonin, S.A., Nicoll, R.S., Mundil, R., Wang, X., Lucas, S.G., 2009. Stratigraphy, biostratigraphy and C-isotopes of the Permian-Triassic non-marine sequence at Dalongkou and Lucaogou, Xinjiang Province, China. J. Asian Earth Sci. 36, 503-520. doi:10.1016/j.jseaes.2008.06.005

McElhinny, M.W., Embleton, B.J.J., Ma, X.H., Zhang, Z.K., 1981. Fragmentation of Asia in the Permian. Nature 293, 212-216.

Mussa, D., 1958. Conifera fóssil do carbonifero superior de Santa Catarina. Boletim Departamento Nacional da Produção Mineral, Divisão de Geologia e Mineralogia 182, $1-23$.

Mussa, D., de Carvalho. R.G., dos Santos, P.R., 1980. Estudo estratigráfico e paleoecológico em ocorrências fossilíferas da Formação Irati, Estado de São Paulo, Brasil. Boletim IGUSP Instituto de Geociéncias da Universidade de São Paulo, 1, 142-149.

Mussa D., 1986. Eustelos Gondwanicos de medullas diafragmadas e a sua posicão estratigrafica. Boletim IG-USP Instituto de Geociéncias da Universidade de São Paulo, $17,11-26$.

Pant, D.D., Singh, V.K., 1987. Xylotomy of some woods from Raniganj Formation (Permian), Raniganj Coalfield, India. Palaeontographica Abteilung B 203, 1-82.

Péron, S., Bourquin, S., Fluteau, F., Guillocheau, F., 2005. Paleoenvironment reconstructions and climate simulations of the Early Triassic $\square$ : Impact of the water and sediment supply on the preservation of fluvial systems. Geodinamica Acta 18, 431-446.

Petriella, B., 1982. Medullopitys menendezii n. sp., leño picnoxilico de gimnospermas del Paleozóico Superior de Mendoza. Argentina. Ameghiniana 19 (3/4), 253-257.

Retallack, G.J., Sheldon, N.D., Carr, P.F., Fanning, M., Thompson, C.A., Williams, M.L., Jones, B.G., Hutton, A., 2011. Multiple Early Triassic greenhouse crises impeded 
recovery from Late Permian mass extinction. Palaeogeography, Palaeoclimatology, Palaeoecology 308 (1), 233-251.

Retallack, G.J., 2013. Permian and Triassic greenhouse crises. Gondwana Research 24, 90_ 103.

Rothwell, G.W., Mapes, G., 2001. Barthelia furcata gen. et sp. nov., with review of Paleozoic coniferophytes and discussion of coniferophyte systematics. Int. J. Plant Sci. 162, 637667.

Rothwell, G.W., Mapes, G., Hernandez-Castillo, G.R., 2005. Hanskerpia gen. nov. and phylogenetic relationships among the most ancient conifers (Voltziales). Taxon 54, 733750.

Royer, D.L., Wilf, P., Janesko, D., Kowalski, E., Dilcher, D., 2005. Correlations of climate and plant ecology to leaf size and shape: potential proxies for the fossil record. Am. J. Bot. 92, 1141-1151. doi:10.3732/ajb.92.7.1141

Sengor, A.M.C., Nat'lin, B.A., 1996. Paleotectonics of Asia: fragments of a synthesis. In: Yin, A., Harrison, T.M. (Eds.). The Tectonic Evolution of Asia. Cambridge University Press, New York, pp. 486-640.

Schweingruber, F.H., 1992. Annual growth rings and growth zones in woody plants in southern Australia. IAWA Bulletin 13, 359-379.

Schweingruber, F.H., 1996. Tree Rings and Environment Dendroecology. Swiss Federal Institute for Forest, Berne, pp. 1- 609.

Schultze-Motel, J., 1961. Gymnospermen-Hölzer aus dem Jura des Nördlichen Harzvorlandes: Protophyllocladoxylon quedlinburgense n. sp. Mber. Dtsch. Akad. Wiss, 3, 418-426.

Scotese, C.R., 2001. Atlas of Earth history, vol. 1. PALEOMAP Project, Arlington, Texas.

Shi, X., Yu, J., Broutin, J., Pons, D., 2015. Junggaropitys, a new gymnosperm stem from the Middle-Late Triassic of Junggar Basin, Northwest China, and its palaeoecological and 
palaeoclimatic implications. Review of Palaeobotany and Palynology 223, 10-20.

Smith, R.M.H., Ward, P.D., 2001. Pattern of vertebrate extinctions across an event bed at the Permian-Triassic boundary in the Karoo Basin of South Africa. Geology 29, 1147-1150. doi:10.1130/0091-7613(2001)029<1147:POVEAA>2.0.CO;2

Sun, F., 1989. On the Late Permian Angara flora of Turfan Basin, Xinjiang, with special reference to the subdivision of Angara Province. -M.Sc. thesis, Nanjing Institute of Geology and Palaeontology, Chinese Academy of Sciences. 1-192 (in Chinese with English abstract).

Sun, Y., Joachimski, M.M., Wignall, P.B., Yan, C., Chen, Y., Jiang, H., Wang, L., Lai, X., 2012. Lethally hot temperatures during the Early Triassic greenhouse. Science 338 (6105), 366-370.

Thomas, S.G., Tabor, N.J., Yang, W., Myers, T.S., Yang, Y., Wang, D., 2011. Palaeosol stratigraphy across the Permian-Triassic boundary, Bogda Mountains, NW China: implications for palaeoenvironmental transition through earth's largest mass extinction. Palaeogeography, Palaeoclimatology, Palaeoecology 308 (1-2), 41-64.

Twitchett, R.J., Looy, C.V., Morante, R., Visscher, H., Wignall, P.B., 2001. Rapid and synchronous collapse of marine and terrestrial ecosystems during the end-Permian biotic crisis. Geology 29, 351. doi:10.1130/0091-7613(2001)029<0351:RASCOM>2.0.CO;2

Wan, M., Yang, W., Wang, J., 2014. Septomedullopitys szei sp. nov., a new gymnospermous wood from Lower Wuchiapingian (Upper Permian) continental deposits of NW China, and its implication for a weakly seasonal humid climate in mid-latitude NE Pangaea. Palaeogeography, Palaeoclimatology, Palaeoecology 407 (1), 1-13.

Wang, Z.Q., 1996. Recovery of vegetation from the terminal Permian mass extinction in North China. Review of Palaeobotany and Palynology 91 (1), 121-142.

Wang, Z.Q., Zhang, Z.P., 1998. Gymnosperms on the eve of the terminal Permian mass 
extinction in North China and their survival strategies. Chinese Science Bulletin, 43 (11), 889-897.

Wartes, M.A., Carroll, A.R., Greene, T.J., 2002. Permian sedimentary record of the TurpanHami Basin and adjacent regions, Northwest China; constraints on postamalgamation tectonic evolution. Geological Society of America Bulletin 114, 131-152.

Xiao, W., Kröner, A., Windley, B.F., 2009. Geodynamic evolution of Central Asia in the Paleozoic and Mesozoic. International Journal of Earth Sciences 98, 1185-1188. doi:10.1007/s00531-009-0418-4

He, J., Wang, S.J., Hilton, J., Shao, L., 2013. Xuanweioxylon scalariforme gen. et sp. nov.: Novel Permian coniferophyte stems with scalariform bordered pitting on secondary xylem tracheids. Review of Palaeobotany and Palynology 197, 152-165.

Yang, W., Liu, Y., Feng, Q., Lin, J., Zhou, D., Wang, D., 2007. Sedimentary evidence of Early-Late Permian mid-latitude continental climate variability, southern Bogda Mountains, NW China. Palaeogeography, Palaeoclimatology, Palaeoecology 252, 239_ 258.

Yang, W., Feng, Q., Liu, Y., Tabor, N., Miggins, D., Crowley, J.L., Lin, J., Thomas, S., 2010. Depositional environments and cyclo- and chronostratigraphy of uppermost Carboniferous-Lower Triassic fluvial-lacustrine deposits, southern Bogda Mountains, NW China - a terrestrial palaeoclimatic record of mid-latitude NE Pangea. Global and Planetary Change 73, 15-113.

Yao, Z.Q., Liu, L.J., Zhang, S., 1994. Permian wood from western Henan, China: implications for palaeoclimatological interpretations. Review of Palaeobotany and Palynology 80 (3), 277-290.

Zhang, X., 1981. Regional Stratigraphic Chart of northwestern China, Branch of Xinjiang Uygur Autonomous Region. Geological Publishing House, Beijing. 496 pp. (in Chinese). 
Zhang, Y., Wang, J., Liu, L., Li, N., 2010. Protophyllocladoxylon jingyuanense sp. nov., a gymnospermous wood of the Serpukhovian (Late Mississippian) from Gansu, Northwest China. Acta Geologica Sinica 84, 257-268.

Ziegler, A.M., Hulver, M.L., Rowley, D.B., 1997. Permian world topography and climate. In: Martini, I.P. (Ed.), Late Glacial and Postglacial Environmental Changes: Pleistocene, Carboniferous-Permian, and Proterozoic. Oxford University Press, Oxford, pp. 111-146.

Zhu, H.C., Ouyang, S., Zhan, J.Z., Wang, Z., 2005. Comparison of Permian palynological assemblages from the Junggar and Tarim basins and their phytoprovincial significance. Review of Palaeobotany and Palynology 136, 181-207. 
Figure captions:

Figure 1: (A) Location of Xinjiang Uygur Autonomous Region. (B) Location of the Taoshuyuan anticline. (C) Geological map of the Taoshuyuan syncline.

Figure 2: Simplified palaeogeographic reconstruction showing the location of the Turpan Basin at $250 \mathrm{Ma}$.

A: Anamia; NC: North China block; SC: South China block. Modified after Domeier and Torsvick, 2014. Reconstruction generated using GPlates software (http://gplates.org).

Figure 3: Sedimentological section for the south limb of the Taoshuyuan syncline where the woody branch was found.

Position of the sample is indicated (XTT-C-4). See Fig. 1C for location.

Figure 4: Turpanopitys taoshuyuanense gen. et sp. nov. A. General view of the specimen XTT-C-4. B. Overview of the pith and the primary xylem of the branchlet (transverse section) and the secondary xylem of the branch (tangential section). Slide number: XTT-C-4a1. C. Close-up of the pith with cracked cavities and the primary xylem of the branchlet (transverse section), red arrows: spirally arranged leaf traces. Slide number: XTT-C-4a1. D. Transverse section showing the isodiametric parenchyma cells in the pith. Slide number: XTT-C-4a1. E. Close up on a leaf trace across a growth-ring boundary (red arrows) in the secondary xylem. Slide number: XTT-C-4a1.

Figure 5: Turpanopitys taoshuyuanense gen. et sp. nov. A. Overview of the pith and the primary xylem of the branchlet (radial section; in the red box) and the secondary xylem (SX) of the main branch (transverse section). The red arrows indicate the lense-like diaphragms and 
the blue arrows indicate the curved diaphragms in the pith. Slide number: XTT-C-4b1. B. Overview of the pith, primary xylem and secondary xylem of the branchlet (transverse section). The area in the blue box is disturbed due to a local maceration during decay. Slide number: XTT-C-4a2. C. Radial section showing one diaphragm in the pith. Slide number: XTT-C-4b1. D. Radial section showing one diaphragm (arrows) in the pith. Slide number: XTT-C-4b2. The slides XTT-C-4b1 and XTT-C-4b2 are perpendicular. E. Radial section showing the small brick-like supporting cells of the diaphragm (the red box in picture C). Slide number: XTT-C-4b1. F. Radial section showing the close-up of the diaphragm (the blue box in picture $\mathrm{C}$ ). The thickness of the diaphragm reduces on the periphery of the pith. The diaphragm disappears at the contact with the initial of the secondary xylem. Slide number: XTT-C-4b1.

Figure 6: Turpanopitys taoshuyuanense gen. et sp. nov. A. Close-up of the diaphragm cells. Slide number: XTT-C-4b1. B. Transverse section showing the endarch primary xylem (arrows) on the pith periphery. Slide number: XTT-C-4a1. C. Radial section showing the helical and reticulate thickenings of the tracheids of primary xylem. Slide number: XTT-C-4b1. D. Transverse section showing the subtle growth-ring boundary, characteristic of "indistinct growth rings" (arrows) in the secondary xylem of the main branch. Slide number: XTT-C4b1. E, F. Radial section showing the uniseriate and biseriate radial pits on the tracheid walls in the branchlet. The biseriate pits are alternate or rarely opposite. Slide number: XTT-C-4b1.

Figure 7: Turpanopitys taoshuyuanense gen. et sp. nov. A. Radial section showing the uniseriate radial pits on the tracheid walls in the main branch. Slide number: XTT-C-4b2. B, C. Radial section showing 1 to 3 rectangular, ovoid or round simple cross-field pits in the branchlet. Slide number: XTT-C-4b1. D. Radial section showing 1 to 3 rectangular, ovoid or 
round simple cross-field pits in the main branch. Slide number: XTT-C-4b2. E. Tangential section showing the homogeneous, uniseriate or biseriate rays. Slide number: XTT-C-4a1. F. Tangential section showing the homogeneous rays; the red arrows indicate tyloses protruding in the lumen of tracheids. Slide number: XTT-C-4a1.

Figure 8: A. The growth rings with the subtle growth-ring boundary, in the main branch; B. Variation in cell radial diameter across growth rings. Growth is left to right. Arrows indicate the growth-ring boundaries.

Figure 9: Right-skewed CSDM curves of five growth rings and cell diameters of growth ring increment. For each ring increment, the percentage of skew for CSDM curves was calculated using Falcon-Lang's (2000a) method. The position at which the CSDM curve reaches the zenith represents the percentage of skew in relation to the total distance between the centres of the CSDM curve to the right of the plot. EW: Early wood, LW Late wood.

Figure 10: Distribution of the woods with Protophyllocladoxylon-type secondary xylem during the Palaeozoic. A. 1. Protophyllocladoxylon jingyuanense B. 1. Protophyllocladoxylon dolianitii; 2. P. derbyi; 3. Medullopitys menendezii; 4. Phyllocladopitys petriellae; 5. Cordaixylon andresii. C. 1. Protophyllocladoxylon natalense; 2. P. henanense; 3. Phyllocladopitys capensis; 4. Megaporoxylon kaokense; 5. Medullopitys sclerotic. D. 1. Protophyllocladoxylon indicum; 2. Turpanopitys taoshuyuanense; 3. Septomedullopitys szei; 4. Septomedullopitys sibirica; 5. Megaporoxylon canalosum; 6. M. antarcticum 

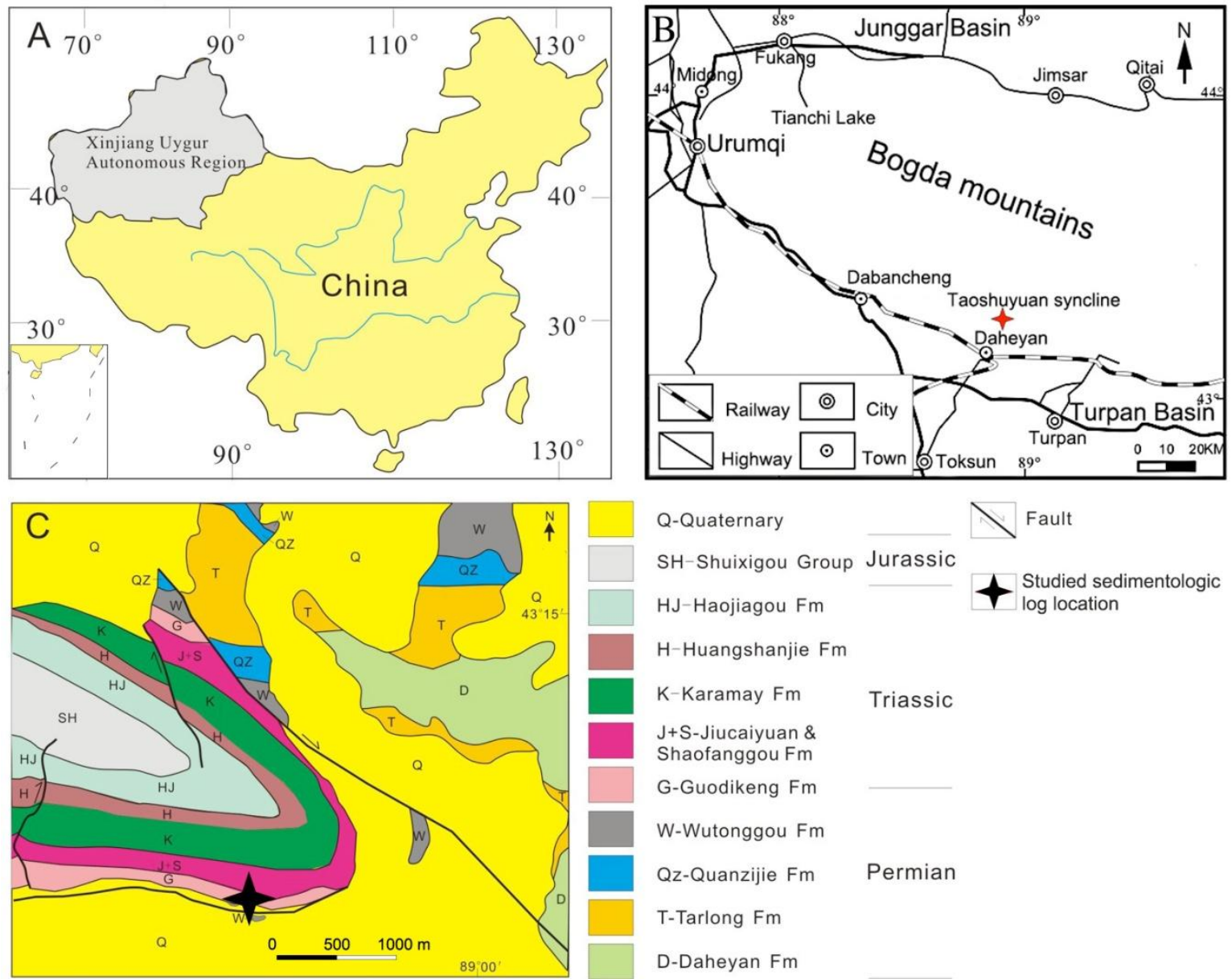

Q-Quaternary

$\searrow$ Fault

SH-Shuixigou Group Jurassic

HJ-Haojiagou Fm

Studied sedimentologic

$\mathrm{H}$-Huangshanjie Fm

K-Karamay $\mathrm{Fm} \quad$ Triassic

$\mathrm{J}+\mathrm{S}$-Jiucaiyuan \&

Shaofanggou $\mathrm{Fm}$

G-Guodikeng Fm

W-Wutonggou Fm

Qz-Quanzijie Fm Permian

T-Tarlong Fm

D-Daheyan Fm

Fig. 1 


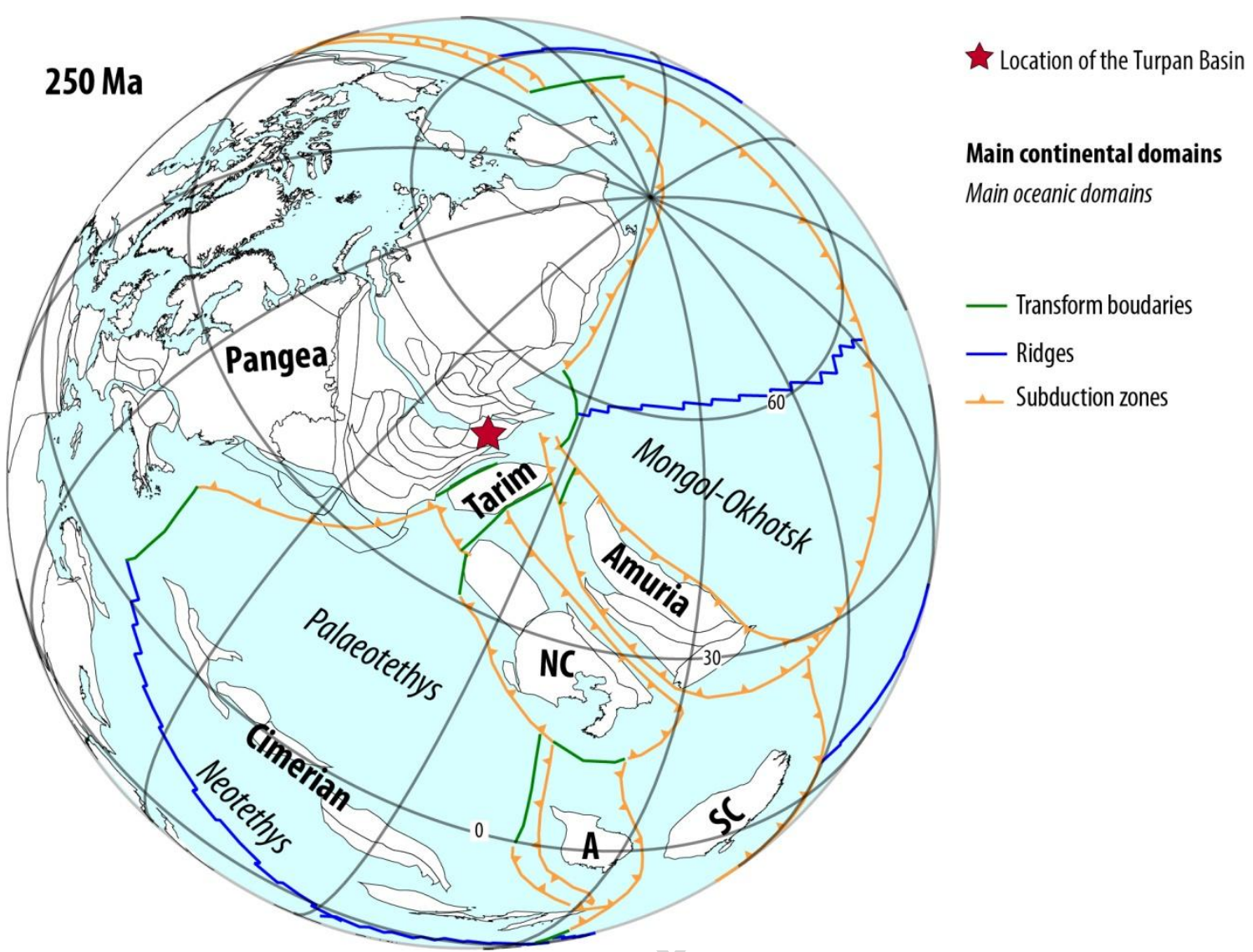

Fig. 2 


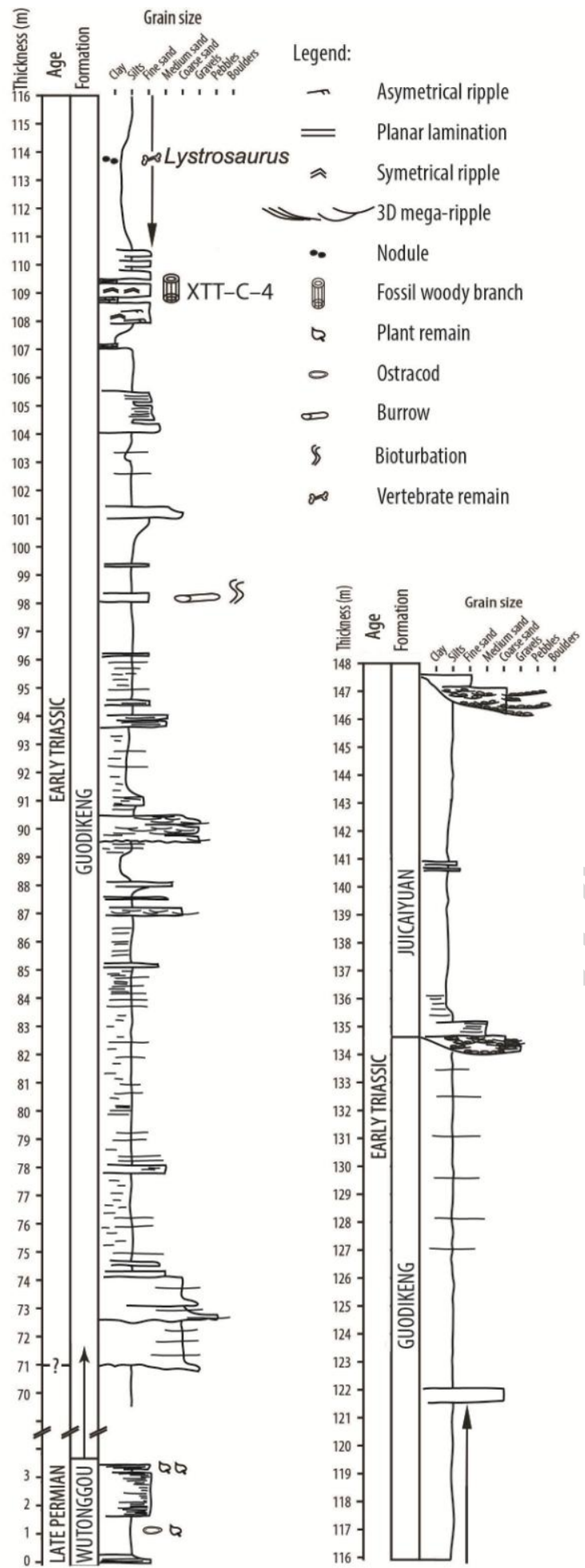

Fig. 3 


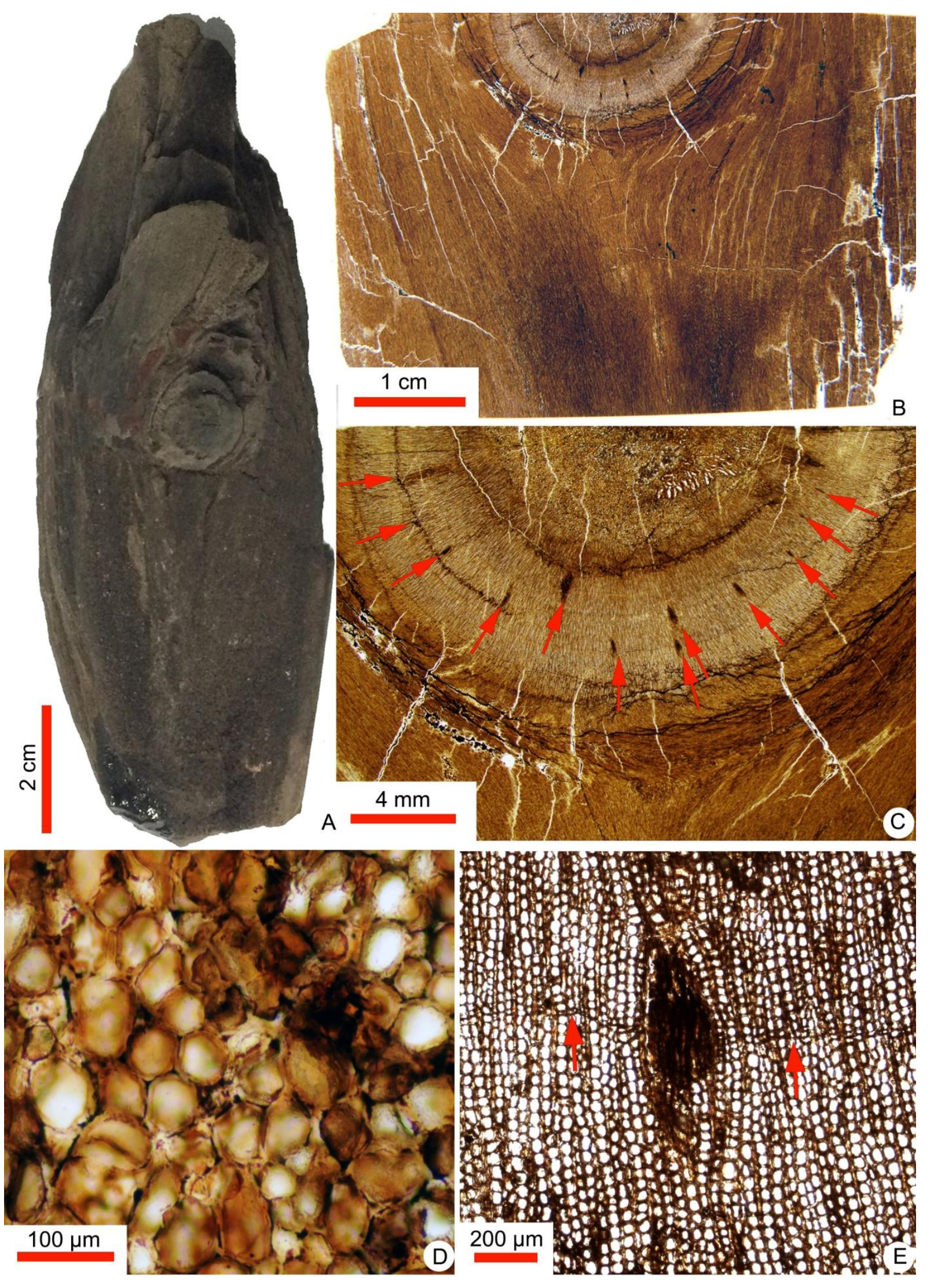

Fig. 4 


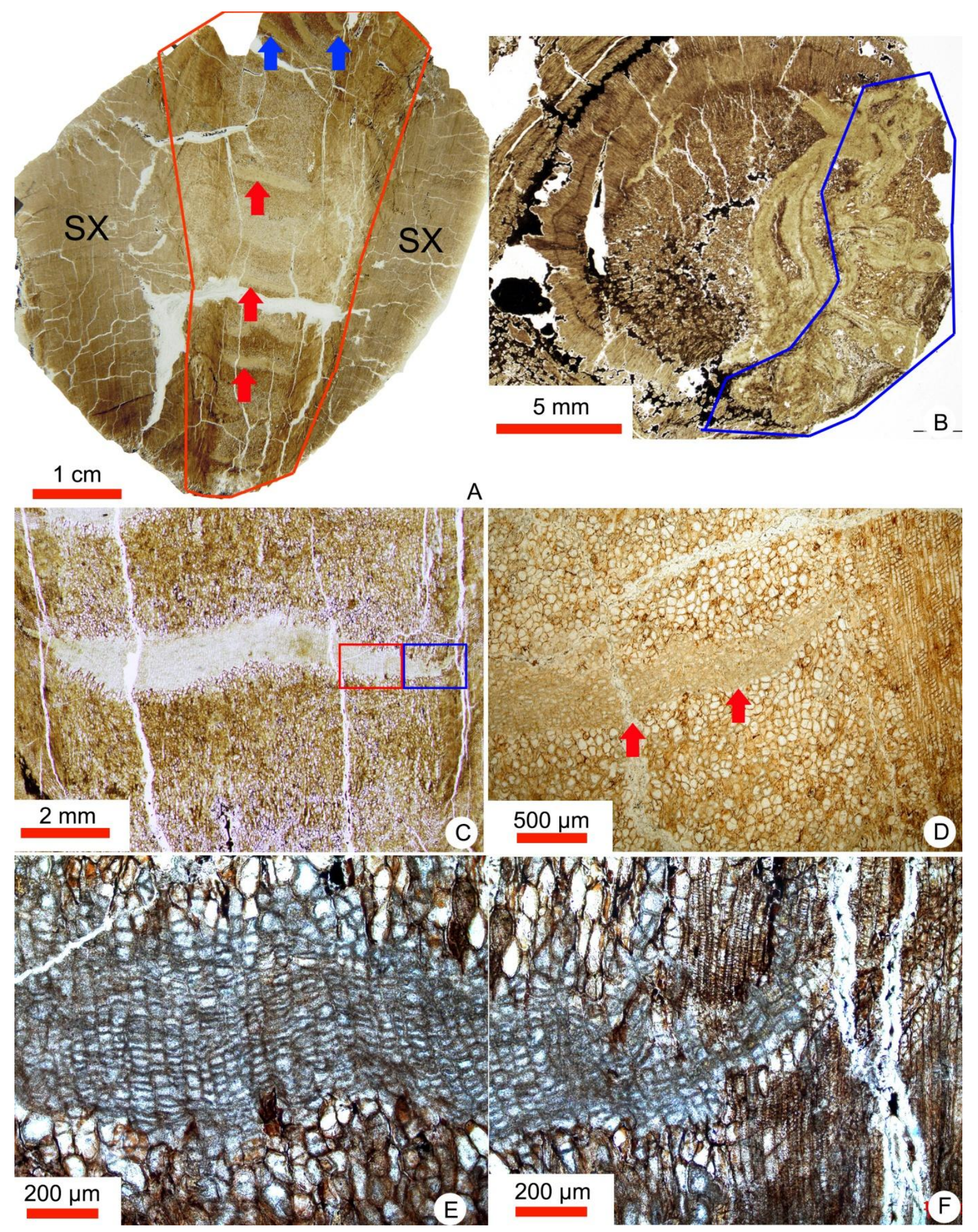

Fig. 5 

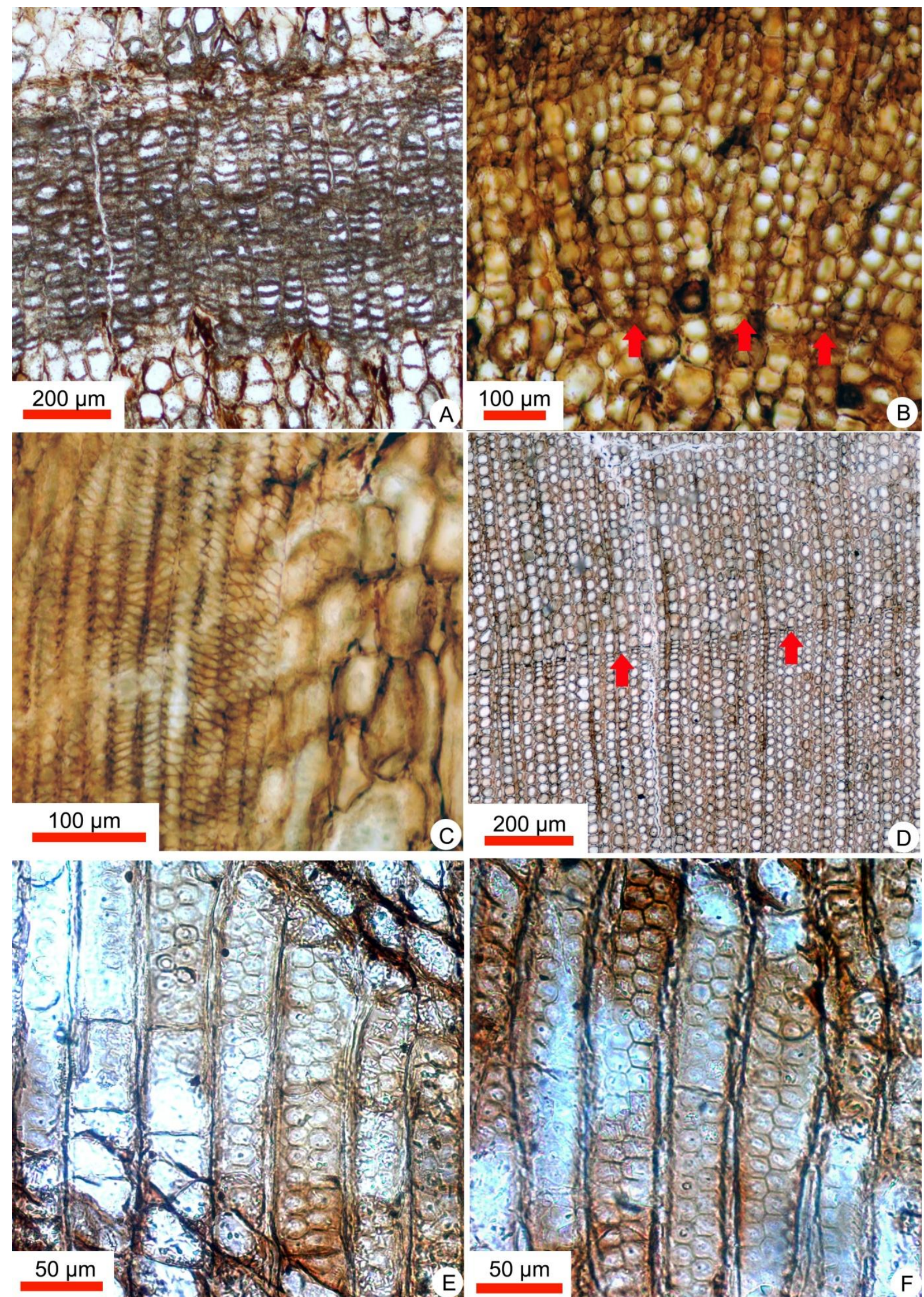

Fig. 6 


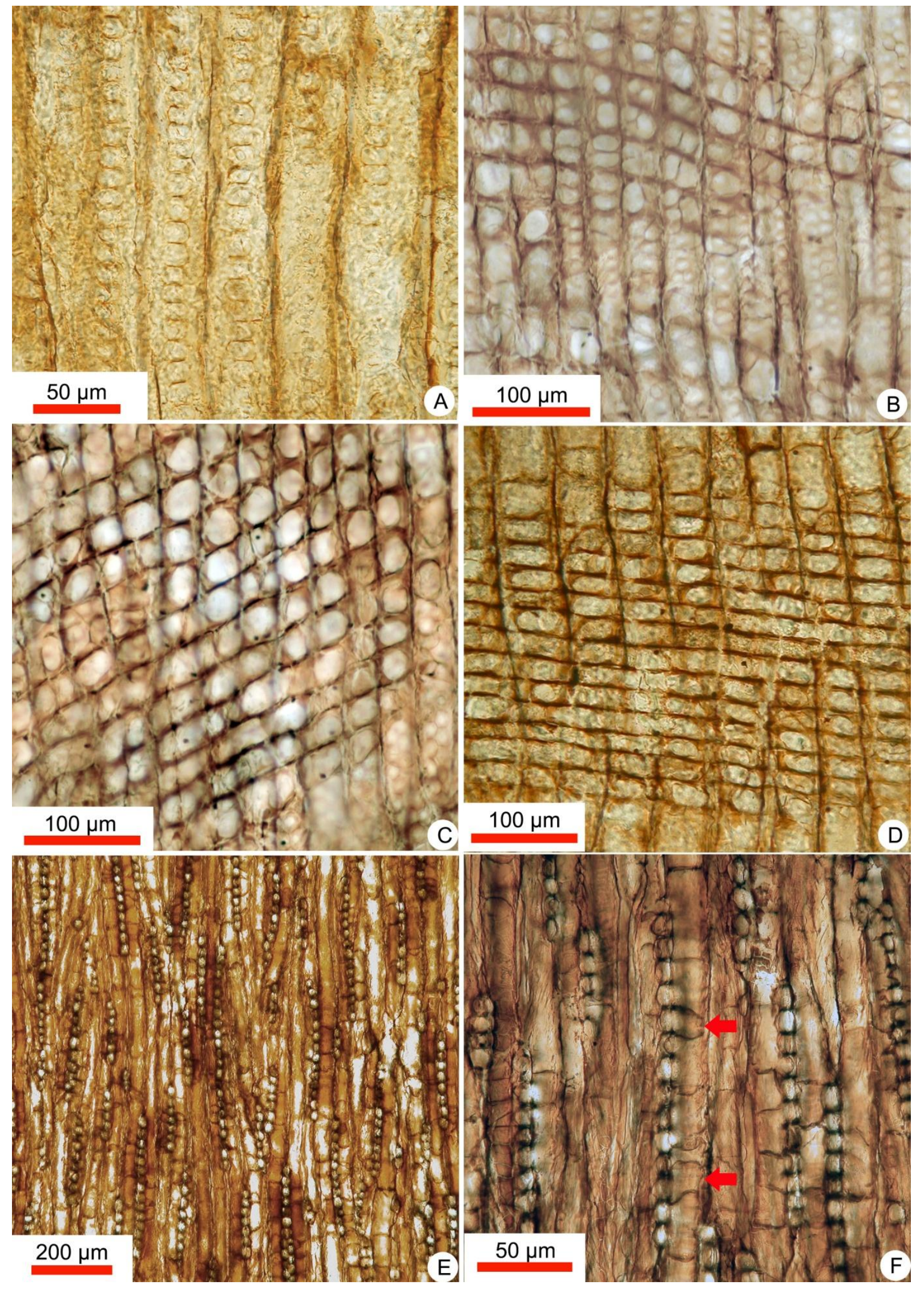

Fig. 7 


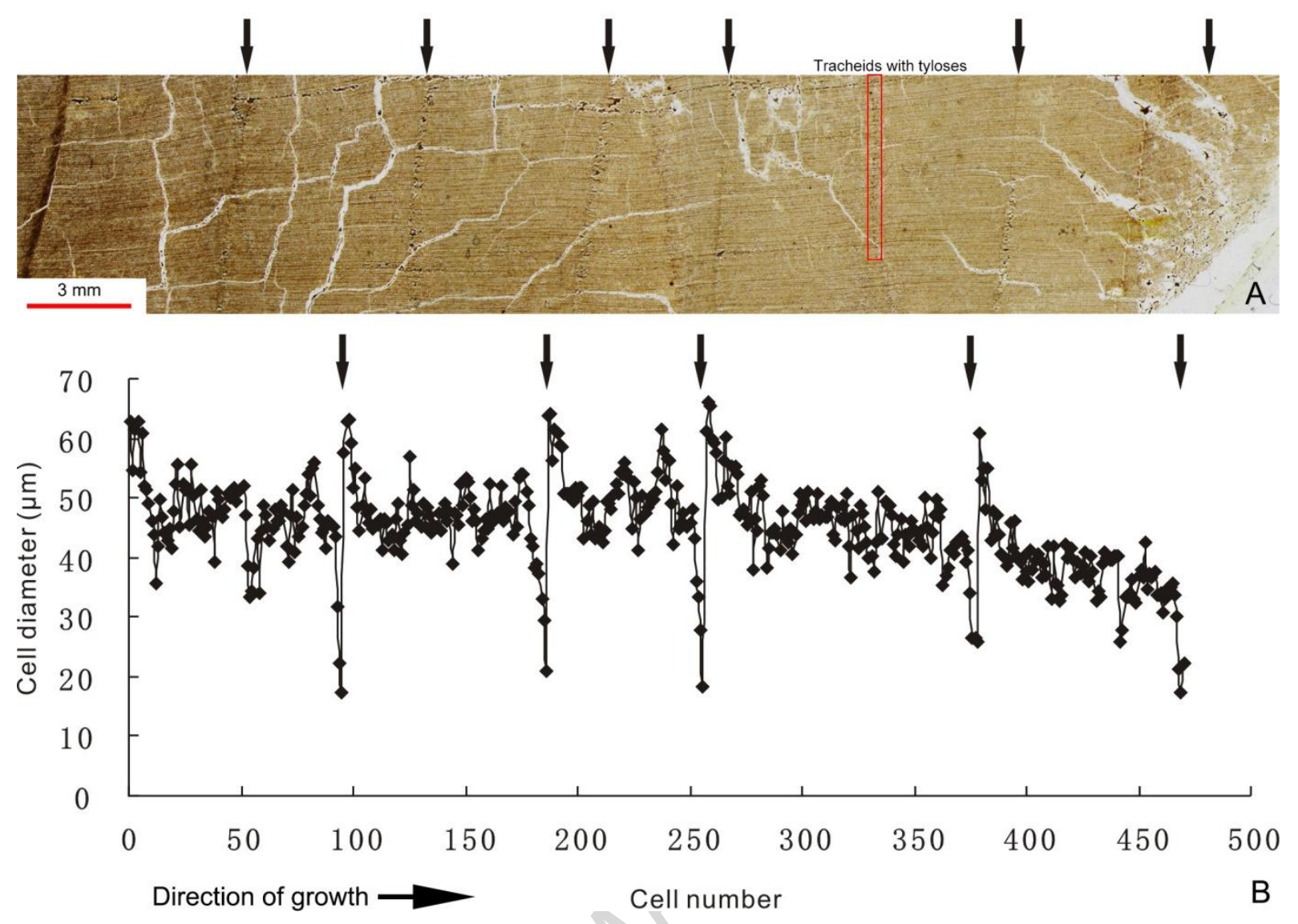

Fig. 8 

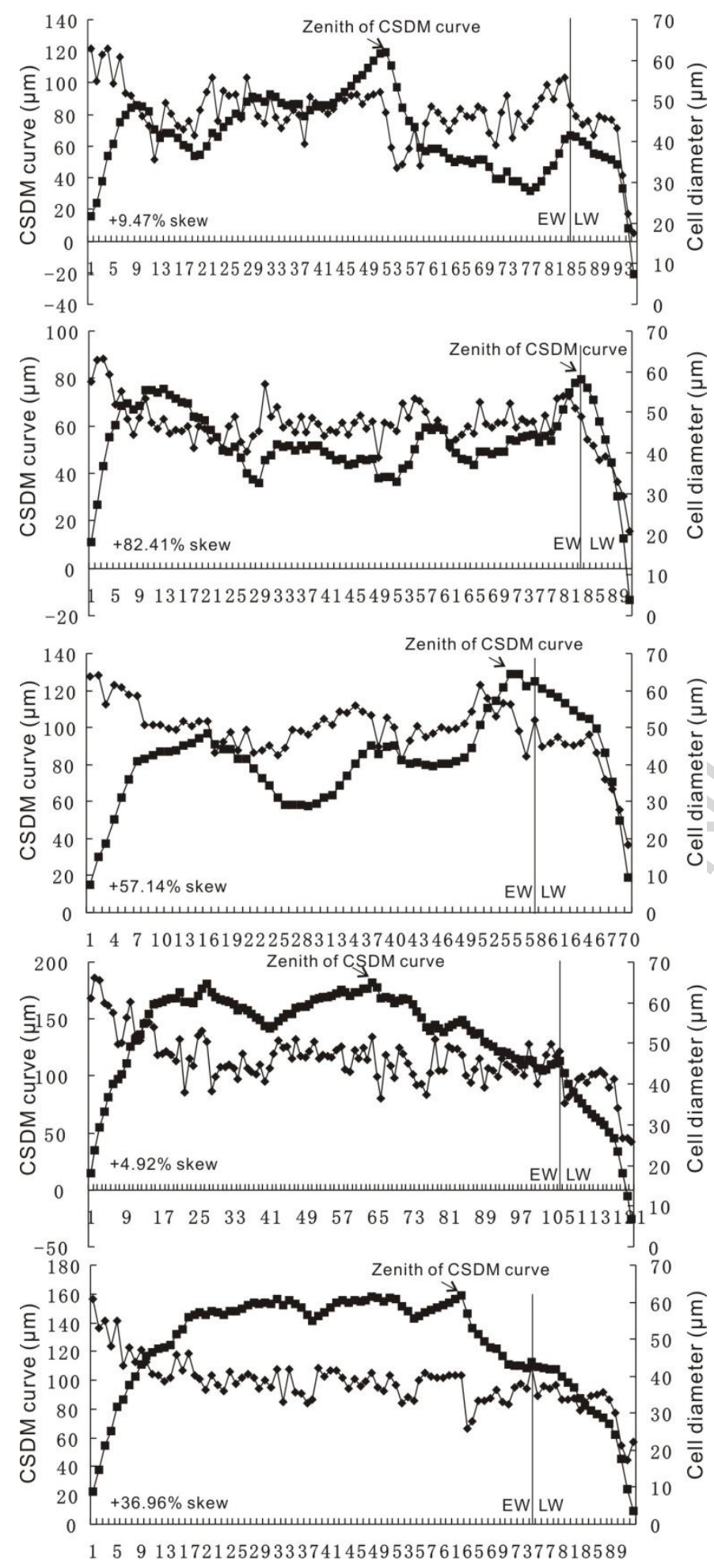

Fig. 9 


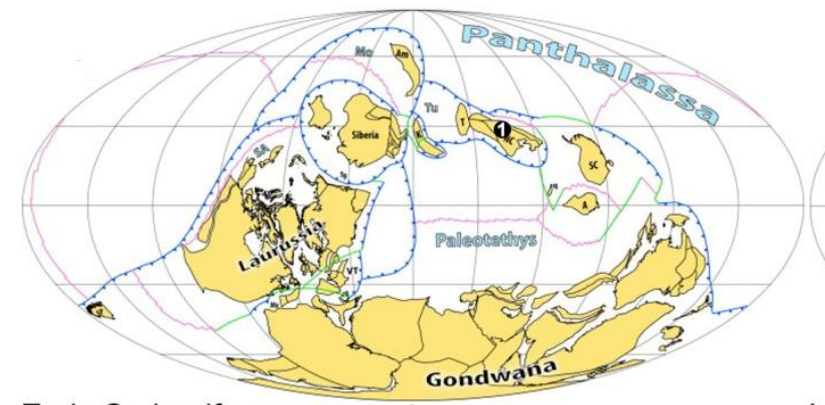

Early Carboniferous

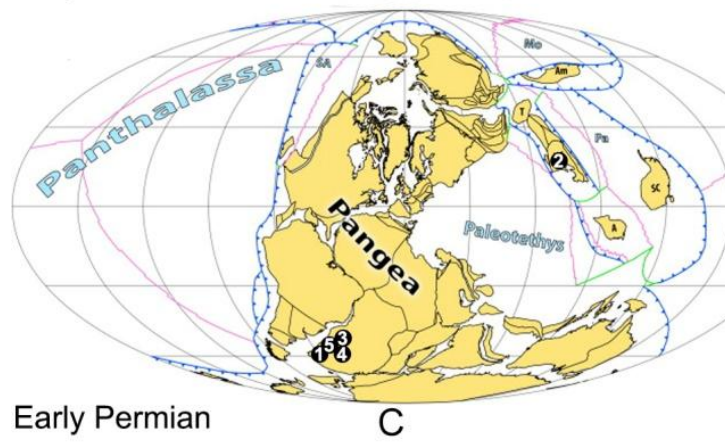

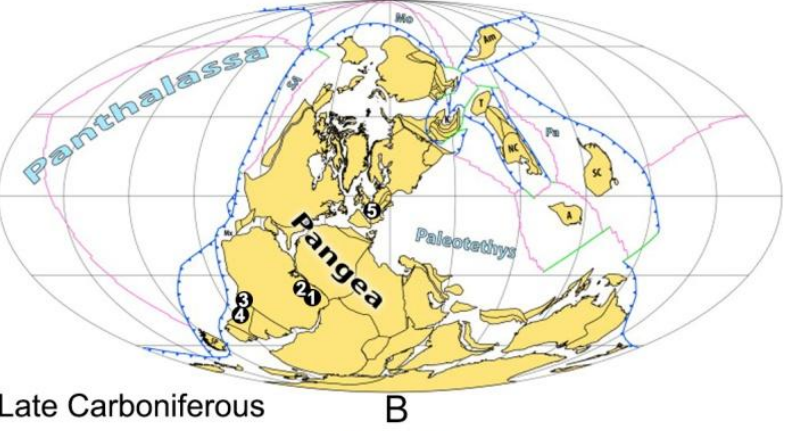

Late Carboniferous

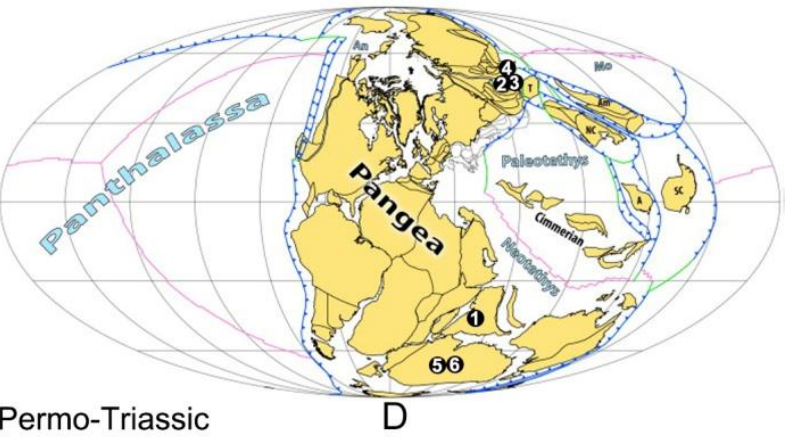

Fig. 10 
Table captions:

Table 1: Comparative features of pith and primary xylem for the species with a Protophyllocladoxylon-type secondary xylem.

Table 2: Results of the quantification of ring markedness parameters for Turpanopitys taoshuyuanense gen. et sp. nov.

Table 3: Comparison of the quantification of ring markedness parameters for Turpanopitys taoshuyuanense gen. et sp. nov. with the five extant taxa taken from the data-base of FalconLang (2000a, b).

Table 4: Distribution of morphographic "species" Protophyllocladoxylon based only secondary xylem structure during the Palaeozoic.

Table 5: Distribution of the species with Protophyllocladoxylon-type secondary xylem during the Palaeozoic. 


\section{Table 1}

\begin{tabular}{|c|c|c|c|c|}
\hline Genus & Pith & Primary xylem & Type locality and age & References \\
\hline $\begin{array}{l}\text { Turpanopitys gen. } \\
\text { nov. }\end{array}$ & $\begin{array}{l}\text { Large, } \\
\text { heterogeneous } \\
\text { with supporting } \\
\text { diaphragms and } \\
\text { isodiametric } \\
\text { parenchyma cells }\end{array}$ & Endarch & $\begin{array}{l}\text { Xinjiang, China; Early } \\
\text { Triassic }\end{array}$ & The present paper \\
\hline $\begin{array}{l}\text { Phyllocladopitys } \\
\text { Kräusel, } 1928\end{array}$ & $\begin{array}{l}\text { Variable, } \\
\text { homogeneous with } \\
\text { different size of } \\
\text { parenchyma cells }\end{array}$ & Mesarch & $\begin{array}{l}\text { South-West Africa; Early } \\
\text { Permian. } \\
\text { Argentina, South America; } \\
\text { early Carboniferous } \\
\text { (Pennsylvanian). }\end{array}$ & $\begin{array}{l}\text { Kräusel, 1928; } \\
\text { Kräusel et al., 1961; } \\
\text { Lepekhina, 1972; } \\
\text { Brea and Césari, } \\
1995\end{array}$ \\
\hline $\begin{array}{l}\text { Medullopitys } \\
\text { Kräusel, } 1928\end{array}$ & $\begin{array}{l}\text { Large, } \\
\text { heterogeneous with } \\
\text { parenchyma cells } \\
\text { and longitudinal } \\
\text { sclerenchyma cell } \\
\text { strands }\end{array}$ & Endarch & $\begin{array}{l}\text { South-West Africa; Early } \\
\text { Permian. }\end{array}$ & $\begin{array}{l}\text { Kräusel, 1928; } \\
\text { Kräusel et al., 1961; } \\
\text { Lepekhina, } 1972\end{array}$ \\
\hline $\begin{array}{l}\text { Megaporoxylon } \\
\text { Kräusel, } 1956\end{array}$ & $\begin{array}{l}\text { Large, } \\
\text { heterogeneous with } \\
\text { parenchyma cells } \\
\text { and secretory } \\
\text { canals }\end{array}$ & Endarch & $\begin{array}{l}\text { South-West Africa and } \\
\text { Antarctica; Early Permian. }\end{array}$ & $\begin{array}{l}\text { Kräusel 1956; } \\
\text { Kräusel et al., 1961; } \\
\text { Lepekhina, 1972; } \\
\text { Maheshwari, 1972; }\end{array}$ \\
\hline $\begin{array}{l}\text { Septomedullopitys } \\
\text { Lepekhina, } 1969\end{array}$ & $\begin{array}{l}\text { Large, septate, } \\
\text { heterogeneous with } \\
\text { branched secretory } \\
\text { canals and } \\
\text { irregularly } \\
\text { distributed bands }\end{array}$ & Endarch & $\begin{array}{l}\text { Russia and China; Late } \\
\text { Permian. }\end{array}$ & $\begin{array}{l}\text { Lepekhina, } 1969 \text {, } \\
\text { 1972; Wan et al., } \\
2014\end{array}$ \\
\hline $\begin{array}{l}\text { Junggaropitys Shi, } \\
\text { Yu, Broutin and } \\
\text { Pons, } 2015\end{array}$ & $\begin{array}{l}\text { Small, } \\
\text { homogeneous with } \\
\text { variable } \\
\text { sclerenrenchyma } \\
\text { cells }\end{array}$ & Endarch & $\begin{array}{l}\text { Xinjiang, China; Middle- } \\
\text { Late Triassic. }\end{array}$ & Shi et al., 2015 \\
\hline
\end{tabular}


Table 2

\begin{tabular}{ccccc}
\hline $\begin{array}{c}\text { Ring } \\
\text { number }\end{array}$ & $\begin{array}{c}\text { Percentage } \\
\text { latewood }\end{array}$ & $\begin{array}{c}\text { Percentage } \\
\text { diminution }\end{array}$ & $\begin{array}{c}\text { Ring Markedness Index } \\
\text { (RMI) }\end{array}$ & $\begin{array}{c}\text { Percentage } \\
\text { skews }\end{array}$ \\
\hline Ring A & $10.5 \%$ & $73.02 \%$ & $7.67 \%$ & $+9.47 \%$ \\
Ring B & $8.79 \%$ & $66.67 \%$ & $5.86 \%$ & $+82.41 \%$ \\
Ring C & $17.14 \%$ & $71.88 \%$ & $12.32 \%$ & $+57.14 \%$ \\
Ring D & $12.30 \%$ & $60.61 \%$ & $7.46 \%$ & $+4.92 \%$ \\
Ring E & $19.57 \%$ & $72.13 \%$ & $14.12 \%$ & $+36.96 \%$ \\
Averages & $13.66 \%$ & $68.86 \%$ & $9.48 \%$ & $+38.18 \%$ \\
\hline
\end{tabular}


Table 3

\begin{tabular}{|c|c|c|c|c|}
\hline Species & $\begin{array}{c}\text { Percentage } \\
\text { latewood }(\%)\end{array}$ & $\begin{array}{c}\text { Percentage } \\
\text { diminution } \\
\qquad \%)\end{array}$ & $\begin{array}{c}\text { Ring } \\
\text { Markedness } \\
\text { Index (RMI) } \\
(\%) \\
\end{array}$ & $\begin{array}{c}\text { Range of } \\
\text { percentage } \\
\text { skews (mean } \\
\text { value) }(\%)\end{array}$ \\
\hline \multicolumn{5}{|l|}{ Deciduous conifer } \\
\hline Larix decidua & $50.00-54.83$ & $71.55-85.91$ & $35.77-44.36$ & $\begin{array}{c}-40.0 \text { to }+7.7(- \\
6.8)\end{array}$ \\
\hline \multicolumn{5}{|l|}{$\begin{array}{l}\text { Evergreen conifers (LRT } \\
\text { in years) }\end{array}$} \\
\hline $\begin{array}{l}\text { Pinus sylvestris (1-3 } \\
\text { years) }\end{array}$ & $41.03-50.00$ & $70.53-77.28$ & $31.56-35.26$ & $\begin{array}{c}-9.1 \text { to }+17.9 \\
(+5.2)\end{array}$ \\
\hline Picea abies (3-5 years) & $25.93-44.19$ & $74.02-\varepsilon$ & $19.90-35.42$ & $\begin{array}{l}0.0 \text { to }+38.2 \\
(+12.0)\end{array}$ \\
\hline Cedrus libani (3-6 years) & $30.77-39.58$ & 62.33 & $20.22-24.68$ & $\begin{array}{c}+35.7 \text { to }+42.9 \\
(+39.0)\end{array}$ \\
\hline $\begin{array}{l}\text { Turpanopitys } \\
\text { taoshuyuanense (? years) }\end{array}$ & 8.79-19.57 & $60.61-73.02$ & $5.86-14.12$ & $\begin{array}{c}+4.92 \text { to }+82.41 \\
\quad(+38.18)\end{array}$ \\
\hline $\begin{array}{l}\text { Araucaria araucana }(3- \\
15 \text { years })\end{array}$ & $10.00-22.50$ & $28.67-51.79$ & $3.17-10.35$ & $\begin{array}{c}+55.0 \text { to }+80.0 \\
(66.7)\end{array}$ \\
\hline
\end{tabular}


Table 4

\begin{tabular}{|c|c|c|c|}
\hline Species & Type locality and age & Climatic zone & References \\
\hline $\begin{array}{l}\text { Protophyllocladox } \\
\text { ylon jingyuanense } \\
\text { Zhang, Wang, Liu } \\
\text { and Li } 2010\end{array}$ & $\begin{array}{l}\text { Gansu, China, northern } \\
\text { hemisphere; Early } \\
\text { Carboniferous. }\end{array}$ & Arid & Zhang et al., 2010 \\
\hline $\begin{array}{l}\text { P. henanense Yao, } \\
\text { Liu and Zhang } \\
1994\end{array}$ & $\begin{array}{l}\text { Henan, China, northern } \\
\text { hemisphere; Early } \\
\text { Permian. }\end{array}$ & Tropical & Yao et al., 1994 \\
\hline $\begin{array}{l}\text { P. dolianitii Mussa } \\
1958\end{array}$ & $\begin{array}{l}\text { Brazil, southern } \\
\text { hemisphere; Late } \\
\text { Carboniferous. }\end{array}$ & & Mussa, 1958 \\
\hline $\begin{array}{l}\text { P. derbyi } \\
\text { (Oliveira) } \\
\text { Maheshwari } 1972\end{array}$ & $\begin{array}{l}\text { Brazil, southern } \\
\text { hemisphere; Late } \\
\text { Carboniferous/ Early } \\
\text { Permian. }\end{array}$ & temperate & $\begin{array}{l}\text { Maheshwari, } \\
1972\end{array}$ \\
\hline $\begin{array}{l}\text { P. indicum Pant } \\
\text { and Singh } 1987\end{array}$ & $\begin{array}{l}\text { India, southern } \\
\text { hemisphere; Late } \\
\text { Permian }\end{array}$ & perate & $\begin{array}{l}\text { Pant and Singh, } \\
1987\end{array}$ \\
\hline $\begin{array}{l}\text { P. natalense } \\
\text { (Warren) Schultze- } \\
\text { Motel } 1961\end{array}$ & $\begin{array}{l}\text { South Africa, southern } \\
\text { hemisphere; Early } \\
\text { Permian }\end{array}$ & Cool temperate & $\begin{array}{l}\text { Schultze-Motel, } \\
1961\end{array}$ \\
\hline
\end{tabular}


Table 5

\begin{tabular}{|c|c|c|c|}
\hline Species & Type locality and age & Climatic zone & References \\
\hline $\begin{array}{l}\text { Turpanopitys } \\
\text { taoshuyuanense } \\
\text { gen. et nov. sp. }\end{array}$ & $\begin{array}{l}\text { Xinjiang, China, northern } \\
\text { hemisphere; Early } \\
\text { Triassic }\end{array}$ & Warm temperate & The present paper \\
\hline $\begin{array}{l}\text { Septomedullopitys } \\
\text { sibirica Lepekhina } \\
1969\end{array}$ & $\begin{array}{l}\text { Kuznetsk Basin, Russia, } \\
\text { northern hemisphere; } \\
\text { Late Permian. }\end{array}$ & Warm temperate & $\begin{array}{l}\text { Lepekhina, 1969, } \\
1972\end{array}$ \\
\hline $\begin{array}{l}\text { Septomedullopitys } \\
\text { szei Wan, Yang } \\
\text { and Wang } 2014\end{array}$ & $\begin{array}{l}\text { Xinjiang, China, northern } \\
\text { hemisphere; Late } \\
\text { Permian }\end{array}$ & & Wan et al., 2014 \\
\hline $\begin{array}{l}\text { Cordaixylon } \\
\text { andresii Césari et } \\
\text { al., } 2015\end{array}$ & $\begin{array}{l}\text { Spain, equator; } \\
\text { Stephanian, Late } \\
\text { Carboniferous }\end{array}$ & & Césari et al., 2015 \\
\hline $\begin{array}{l}\text { Phyllocladopitys } \\
\text { petriellae Brea } \\
\text { and César } 1995\end{array}$ & $\begin{array}{l}\text { Argentina, southern } \\
\text { hemisphere; early Late } \\
\text { Carboniferous }\end{array}$ & Cool temperate & $\begin{array}{l}\text { Brea and Césari, } \\
1995\end{array}$ \\
\hline $\begin{array}{l}\text { Medullopitys } \\
\text { menendezii } \\
\text { Petriella } 1982\end{array}$ & $\begin{array}{l}\text { Argentina, southern } \\
\text { hemisphere; Late } \\
\text { Carboniferous }\end{array}$ & & Petriella, 1982 \\
\hline $\begin{array}{l}\text { Phyllocladopitys } \\
\text { capensis Kräusel, } \\
1928\end{array}$ & $\begin{array}{l}\text { South-West Africa, } \\
\text { southern hemisphere; } \\
\text { Early Permian. }\end{array}$ & Cool temperate & $\begin{array}{l}\text { Kräusel, 1928; } \\
\text { Kräusel et al., } \\
\text { 1961; Lepekhina, } \\
1972\end{array}$ \\
\hline $\begin{array}{l}\text { Megaporoxylon } \\
\text { kaokense Kräusel } \\
1956\end{array}$ & $\begin{array}{l}\text { South-West Africa, } \\
\text { southern hemisphere; } \\
\text { Early Permian }\end{array}$ & Cool temperate & $\begin{array}{l}\text { Kräusel, 1956; } \\
\text { Kräusel et al., } \\
\text { 1961; Lepekhina, } \\
1972\end{array}$ \\
\hline $\begin{array}{l}\text { Medullopitys } \\
\text { sclerotic Kräusel } \\
1928\end{array}$ & $\begin{array}{l}\text { South-West Africa, } \\
\text { southern hemisphere; } \\
\text { Early Permian. }\end{array}$ & Cool temperate & $\begin{array}{l}\text { Kräusel, 1928; } \\
\text { Kräusel et al., } \\
\text { 1961; Lepekhina, } \\
1972\end{array}$ \\
\hline $\begin{array}{l}\text { Megaporoxylon } \\
\text { canalosum } \\
\text { Maheshwari } 1972\end{array}$ & $\begin{array}{l}\text { Antarctica, southern } \\
\text { hemisphere; Middle/Late } \\
\text { Permian }\end{array}$ & Cool temperate & Maheshwari, 1972 \\
\hline $\begin{array}{l}\text { Megaporoxylon } \\
\text { antarcticum } \\
\text { Maheshwari } 1972\end{array}$ & $\begin{array}{l}\text { Antarctica, southern } \\
\text { hemisphere; Middle/Late } \\
\text { Permian }\end{array}$ & $\begin{array}{l}\text { Cold/cool } \\
\text { temperate }\end{array}$ & Maheshwari, 1972 \\
\hline
\end{tabular}


Highlights

A novel woody branch, Turpanopitys taoshuyuanensis gen. et sp. nov., discovered in Early Triassic deposits of the Turpan Basin, Northwest China.

Its intraseasonal conditions and leaf longevity patterns were discussed.

The palaeoclimatic conditions were discussed. 